\title{
Early Paleogene variations in the calcite compensation depth: new constraints using old borehole sediments from across Ninetyeast Ridge, central Indian Ocean
}

\author{
B. S. Slotnick ${ }^{1}$, V. Lauretano ${ }^{2}$, J. Backman ${ }^{3}$, G. R. Dickens ${ }^{1,3}$, A. Sluijs ${ }^{2}$, and L. Lourens ${ }^{2}$ \\ ${ }^{1}$ Department of Earth Sciences, Rice University, Houston, TX 77005, USA \\ ${ }^{2}$ Department of Earth Sciences, Utrecht University, 3508 TA Utrecht, the Netherlands \\ ${ }^{3}$ Department of Geological Sciences, Stockholm University, 10691 Stockholm, Sweden
}

Correspondence to: B. S. Slotnick (bss2@ rice.edu)

Received: 25 June 2014 - Published in Clim. Past Discuss.: 8 August 2014

Revised: 9 December 2014 - Accepted: 11 February 2015 - Published: 17 March 2015

\begin{abstract}
Major variations in global carbon cycling occurred between 62 and $48 \mathrm{Ma}$, and these very likely related to changes in the total carbon inventory of the oceanatmosphere system. Based on carbon cycle theory, variations in the mass of the ocean carbon should be reflected in contemporaneous global ocean carbonate accumulation on the seafloor and, thereby, the depth of the calcite compensation depth (CCD). To better constrain the cause and magnitude of these changes, the community needs early Paleogene carbon isotope and carbonate accumulation records from widely separated deep-sea sediment sections, especially including the Indian Ocean. Several CCD reconstructions for this time interval have been generated using scientific drill sites in the Atlantic and Pacific oceans; however, corresponding information from the Indian Ocean has been extremely limited. To assess the depth of the CCD and the potential for renewed scientific drilling of Paleogene sequences in the Indian Ocean, we examine lithologic, nannofossil, carbon isotope, and carbonate content records for late Paleocene - early Eocene sediments recovered at three sites spanning Ninetyeast Ridge: Deep Sea Drilling Project (DSDP) Sites 213 (deep, east), 214 (shallow, central), and 215 (deep, west). The disturbed, discontinuous sediment sections are not ideal, because they were recovered in single holes using rotary coring methods, but remain the best Paleogene sediments available from the central Indian Ocean. The $\delta^{13} \mathrm{C}$ records at Sites 213 and 215 are similar to those generated at several locations in the Atlantic and Pacific, including the prominent high in $\delta^{13} \mathrm{C}$ across the Paleocene carbon isotope maximum (PCIM)
\end{abstract}

at Site 215, and the prominent low in $\delta^{13} \mathrm{C}$ across the early Eocene Climatic Optimum (EECO) at both Site 213 and Site 215. The Paleocene-Eocene thermal maximum (PETM) and the K/X event are found at Site 213 but not at Site 215, presumably because of coring gaps. Carbonate content at both Sites 213 and 215 drops to $<5 \%$ shortly after the first occurrence of Discoaster lodoensis and the early Eocene rise in $\delta^{13} \mathrm{C}(\sim 52 \mathrm{Ma})$. This reflects a rapid shoaling of the CCD, and likely a major decrease in the net flux of ${ }^{13} \mathrm{C}$-depleted carbon to the ocean. Our results support ideas that major changes in net fluxes of organic carbon to and from the exogenic carbon cycle occurred during the early Paleogene. Moreover, we conclude that excellent early Paleogene carbonate accumulation records might be recovered from the central Indian Ocean with future scientific drilling.

\section{Introduction}

Pronounced changes in global carbon cycling characterize a $14 \mathrm{Myr}$ window of the early Paleogene from 62 to $48 \mathrm{Ma}$. As perhaps best expressed in stable carbon isotope records of marine carbonate (Shackleton, 1986; Zachos et al., 2001, 2010; Slotnick et al., 2012), large-magnitude $\delta^{13} \mathrm{C}$ perturbations span both long ( $>1 \mathrm{Myr})$ and short $(<0.2 \mathrm{Myr})$ time intervals (Fig. 1). A prominent rise in $\delta^{13} \mathrm{C}$ begins at ca. $62 \mathrm{Ma}$ and reaches a Cenozoic high at ca. $58 \mathrm{Ma}$. From this Paleocene carbon isotope maximum (PCIM), $\delta^{13} \mathrm{C}$ drops over $\sim 5 \mathrm{Myr}$, culminating in a minimum near the start of the 
early Eocene climatic optimum (EECO) at ca. $53 \mathrm{Ma}$. The $\delta^{13} \mathrm{C}$ rises over the next $4 \mathrm{Myr}$, such that values at $49 \mathrm{Ma}$ are nearly the same as at $62 \mathrm{Ma}$. Superimposed on this major oscillation were several brief carbon isotope excursions (CIEs), when the $\delta^{13} \mathrm{C}$ decreased significantly within 10 to $50 \mathrm{ka}$, and recovered within another 50 to $200 \mathrm{kyr}$ (Cramer et al., 2003; Nicolo et al., 2007; Galeotti et al., 2010; Stap et al., 2010). The Paleocene-Eocene thermal maximum (PETM) at ca. 56 Ma (Westerhold and Röhl, 2009; Charles et al., 2011) represents the extreme case (e.g., Kennett and Stott, 1991; Sluijs et al., 2007).

Both the long-term and short-term $\delta^{13} \mathrm{C}$ perturbations (Fig. 1) have been attributed to major changes in organic carbon fluxes to and from the ocean-atmosphere system (Shackleton, 1986; Dickens et al., 1995; Kurtz et al., 2003; Sluijs et al., 2007; Komar et al., 2013). The rises in $\delta^{13} \mathrm{C}$ toward the PCIM and after the EECO reflect net removal of ${ }^{13} \mathrm{C}$ depleted carbon from the ocean-atmosphere, and the drop in $\delta^{13} \mathrm{C}$ toward the EECO represents net addition of ${ }^{13} \mathrm{C}$ depleted carbon to the ocean-atmosphere; the CIEs, in turn, mark abrupt injections of ${ }^{13} \mathrm{C}$-depleted carbon followed by partial sequestration. Controversy surrounds the cause and magnitude of these carbon flux changes because they are difficult to reconcile with conventional models of global carbon cycling (e.g., Dickens, 2003; Komar et al., 2013).

Records of deep-sea carbonates may constrain perspectives of early Paleogene carbon cycling considerably (Dickens et al., 1997; Zeebe et al., 2009; Leon-Rodriguez and Dickens, 2010; Cui et al., 2011; Komar et al., 2013). Calcite solubility in the deep ocean generally increases with depth, principally because of greater pressure. At constant calcium ion concentrations $\left[\mathrm{Ca}^{2+}\right]$, higher carbonate ion concentrations $\left[\mathrm{CO}_{3}^{2-}\right]$ are therefore necessary to maintain calcite saturation. By contrast, $\left[\mathrm{CO}_{3}^{2-}\right]$ generally decreases with depth. The combination of both factors leads to depth horizons in the ocean that impact calcite preservation on the seafloor (e.g., Broecker and Peng, 1982; Boudreau et al., 2010). From the perspective of the sedimentary record, the lysocline is the depth where calcite dissolution first becomes apparent (Kennett, 1982), and where calcite dissolution rates accelerate. By contrast, the calcite compensation depth (CCD) is the depth where calcite dissolution balances calcite "rain" from above. Although both terms come with caveats (Boudreau et al., 2010), the CCD generally lies hundreds of meters below the lysocline. For this study, we equate the $\mathrm{CCD}$ to where the weight percent of $\mathrm{CaCO}_{3}$ drops below $<10 \%$ (Broecker, 2008; Boudreau et al., 2010). This is appropriate in most low-latitude, open-ocean settings where terrigenous or biosiliceous dilution is not important.

Over long time frames, $\left[\mathrm{CO}_{3}^{2-}\right]$ relates to the total mass of carbon in the ocean (Zeebe and Westbroek, 2003). The long-term rises and drops in $\delta^{13} \mathrm{C}$ across the early Paleogene might therefore respectively coincide with slow shoaling and slow deepening of the lysocline and CCD (Hancock et al.,
2007; Kump et al., 2009; Komar et al., 2013). Alternatively, the CIEs should manifest as rapid rises in the lysocline and $\mathrm{CCD}$, followed by rapid falls, the latter sometimes represented by excess calcite accumulation, referred to as "carbonate overcompensation" (e.g., Dickens et al., 1997; Zachos et al., 2005; Leon-Rodriquez and Dickens, 2010; Kelly et al., 2010). Crucially, on both long and short time frames, the magnitude and timing of such changes should relate to amounts and rates of carbon added to or removed from the ocean and atmosphere (Dickens et al., 1997; Cui et al., 2011; Komar et al., 2013). Early work regarding Cenozoic evolution of the CCD (Berger, 1972; van Andel, 1975) indicated limited variation during the early Paleogene. However, more recent records support significant changes in carbonate accumulation over this time, indicating a dynamic CCD on the million-year timescale (e.g., Rea and Lyle, 2005; LeonRodriguez and Dickens, 2010; Pälike et al., 2012), as well as across some of the CIEs (e.g., Zachos et al., 2005; Stap et al., 2009; Cui et al., 2011).

The long-term CCD record between 62 and 52 Ma remains poorly constrained (Pälike et al., 2012), especially for the Indian Ocean. Moreover, CCD records prior to $52 \mathrm{Ma}$ have not been tightly coupled to $\delta^{13} \mathrm{C}$ records. In this study, we aim to (1) generate early Paleogene carbonate content and $\delta^{13} \mathrm{C}$ records at three Deep Sea Drilling Project (DSDP) sites in the Indian Ocean, (2) examine these records with current perspectives for global carbon cycling between 62 and $48 \mathrm{Ma}$, and (3) establish whether better records might be collected with future drilling.

\section{The central Indian Ocean and DSDP Leg 22}

\subsection{Bathymetry and basement origin}

Three large-scale features characterize the bathymetry of the central Indian Ocean, loosely defined as the region between 5 and $15^{\circ} \mathrm{S}$ latitude and 75 and $100^{\circ} \mathrm{E}$ longitude (Fig. 2). In the middle lies the north-south-oriented Ninetyeast Ridge. This $\sim 4600 \mathrm{~km}$ long (from $\sim 10^{\circ} \mathrm{N}$ to $\sim 31^{\circ} \mathrm{S}$ ) parapet separates two abyssal plain regions: Wharton Basin and Cocos Basin to the east, and the Mid-Indian Basin to the west. The ridge was generated by "hotspot volcanism" as the Indo-Australian Plate moved north over the Kerguelen plume; ages of basalt along the ridge systematically become younger to the south (Fig. 2) (Saunders et al., 1991; Frey et al., 2011).

The surrounding plains are floored by oceanic crust formed along the Southeastern Indian Ridge (SEIR) and Central Indian Ridge (CIR) during the Late Cretaceous through middle Paleogene, as indicated by tholeiitic basalt recovered and dated at several DSDP sites (Frey et al., 1977). Reconstructing paleo-positions in these low-lying abyssal plains is complicated because of broad diffusive plate boundaries, and because of multiple stages of rotation throughout much of the Cenozoic (Patriat and Achacha, 1984; Cande et al., 2010). 




Figure 1. Bulk carbonate $\delta^{13} \mathrm{C}$ records and calcareous intervals for several locations placed onto a current timescale (Option 1; Westerhold et al., 2008). Stable isotope records include those at DSDP Site 577 (North Pacific; Shackleton et al., 1985), ODP Site 1262 (central Atlantic; Zachos et al., 2010) and Mead Stream (South Pacific; Slotnick et al., 2012). The subsidence curve for Site 259 (eastern Indian Ocean; blue) was adapted from (van Andel, 1975), while subsidence curves for Sites 1215, U1370, U1331, 1219, and 1220 (equatorial Pacific, purple) were adapted from various sources (Rea and Lyle, 2005; Leon-Rodriguez et al., 2010; Pälike et al., 2010). Plotted curves, when solid, indicate carbonate contents $>10 \%$, but when dashed they indicate carbonate contents $<10 \%$. Importantly, curves are lightly dotted when no data are available (such as for much of the early Eocene at Sites 1219 and 1220, as noted by Hancock et al., 2007). The dark-brown solid line denotes reconstructed and predicted CCD, consistent with carbonate content data and subsidence curves of sites from previous studies. The biozonal scheme adopted is that of Martini (1971). Blue and red triangles represent base and top occurrences of key calcareous nannofossils. Ages of calcareous nannofossil biohorizons are those proposed by Agnini et al. $(2006,2007)$ recalibrated using Option 1 of Westerhold et al. (2008). Hyperthermals, including PETM, H, I, and K/X, and longer-duration intervals (PCIM and EECO) derived from $\delta^{13} \mathrm{C}$ records.

Nonetheless, ages of basalt throughout the plains and basins surrounding Ninetyeast Ridge generally become younger to the south (Fig. 2).

\subsection{Sites 213, 214, and 215}

This study focuses on three DSDP (Leg 22) sites straddling Ninetyeast Ridge (von der Borch and Sclater, 1974; Fig. 2). Site 213 is located $\sim 500 \mathrm{~km}$ east of Ninetyeast Ridge at $10^{\circ} 12.71^{\prime} \mathrm{S}, 93^{\circ} 53.77^{\prime} \mathrm{E}$, and $5601 \mathrm{~m}$ below sea level (m b.s.l.). Site 214 lies on the crest of Ninetyeast Ridge at $11^{\circ} 20.21^{\prime} \mathrm{S}, 88^{\circ} 43.08^{\prime} \mathrm{E}$, and $1655 \mathrm{mb}$ b.s.l. Site 215 is located $\sim 300 \mathrm{~km}$ west of Ninetyeast Ridge at $8^{\circ} 07.30^{\prime} \mathrm{S}$, $86^{\circ} 47.50^{\prime} \mathrm{E}$, and $5309 \mathrm{~m}$ b.s.l.
All three sites cored basalt of early Paleogene age (Fig. 2). The igneous basement is approximately 56,62 , and $59 \mathrm{Ma}$ at Sites 213, 214, and 215, respectively (MacDougall, 1977; Peirce, 1978; Frey et al., 2011). Given the tectonic history for the region, all three sites were located further south and in shallower water during the early Paleogene. Plate reconstructions have the sites at $\sim 30^{\circ} \mathrm{S}$ in the late Paleocene (ODSN, 2011). Sites 213 and 215 were located at the SEIR crest at the time of basalt emplacement, presumably $\sim 2.75 \mathrm{~km}$ b.s.1. Site 214 was near or above the sea surface until $61 \mathrm{Ma}$. Lowermost sediment recovered at Site 214 contains glauconitic silt with gastropods and bivalves, as well as lignite and tuff.

Coring operations recovered $139 \mathrm{~m}$ of pelagic sediment at Site $213,311 \mathrm{~m}$ of pelagic sediment and $35 \mathrm{~m}$ of neritic sed- 




Figure 2. Modern bathymetric map of the northeastern Indian Ocean with the area of interest (white rectangle). Locations of Sites 213, 214, and 215 are labeled with green boxes. Five additional and relevant site locations are denoted in blue boxes. Ages marked along Ninetyeast Ridge are derived from Frey et al. (2011). Other seafloor ages, also on a million-year timescale, are marked by yellow-green numbers. The open white rectangle indicates the specific area of focus.

iment at Site 214 (excluding lowermost volcaniclastic material), and $113 \mathrm{~m}$ of pelagic sediment at Site 215 (von der Borch and Sclater, 1974). Sediment age was determined primarily through calcareous biochronology. This study focuses on cores containing upper Paleocene and lower to middle Eocene sediment (Figs. 3-5), which remain the best available early Paleogene sections recovered from the central Indian Ocean. Studied intervals comprise a range of lithologies, but especially nannofossil ooze and clay. Of primary interest are occasional clay-rich horizons within nannofossil ooze, and major shifts from nannofossil ooze to clay, such as within lower Eocene sediments at Site 213 (Core 14) and at Site 215 (Core 9).

\subsection{Previous work on early Paleogene sequences}

Previous investigations of lower Paleogene sediment at Sites 213, 214, and 215 (von der Borch and Sclater, 1974; McGowran, 1974; Gartner, 1974; Bukry, 1974; Hovan and Rea, 1992; Zachos et al., 1992; Berggren and Norris, 1997; Ravizza et al., 2001; Tremolada and Bralower, 2004) provide age constraints. Much of this work concerns nannofossil and foraminiferal biostratigraphy and was conducted at low spatial resolution between samples, except for studies across the PETM at Site 213 (Ravizza et al., 2001; Tremolada and Bralower, 2004). Moreover, absolute ages on Paleogene timescales have changed significantly over the past 40 years.
For proper comparison of various data sets, it is necessary to place results onto a common and current early Paleogene timescale.

\section{Methods}

\subsection{Stratigraphic log and samples}

In contrast to most paleoceanographic expeditions over the last two decades, only one hole was drilled at each site. Furthermore, drilling employed the rotary coring method (Storms, 1990), in contrast to the preferred advanced hydraulic piston coring (APC) method. The combination almost necessarily leads to churned-up sediment and incomplete core recovery. This is confirmed for the sites of interest through photographs and logs that show some highly disturbed intervals (Fig. 6), as well as numerous cores less than $9.5 \mathrm{~m}$ in length, even though drilling generally advanced by this amount (von der Borch and Sclater, 1974). More problematic are "core gaps" that may exist between successive cores (Ruddiman et al., 1987; Hagelberg et al., 1992; Dickens and Backman, 2013). As discovered on drilling expeditions ca. 1985-1987, typically about $1 \mathrm{~m}$ (but up to $3 \mathrm{~m}$ or more) of sediment is missing between successive hydraulic piston cores, even when $9.5 \mathrm{~m}$ long cores are completely full of sediment. We assume that such core gaps, which result 


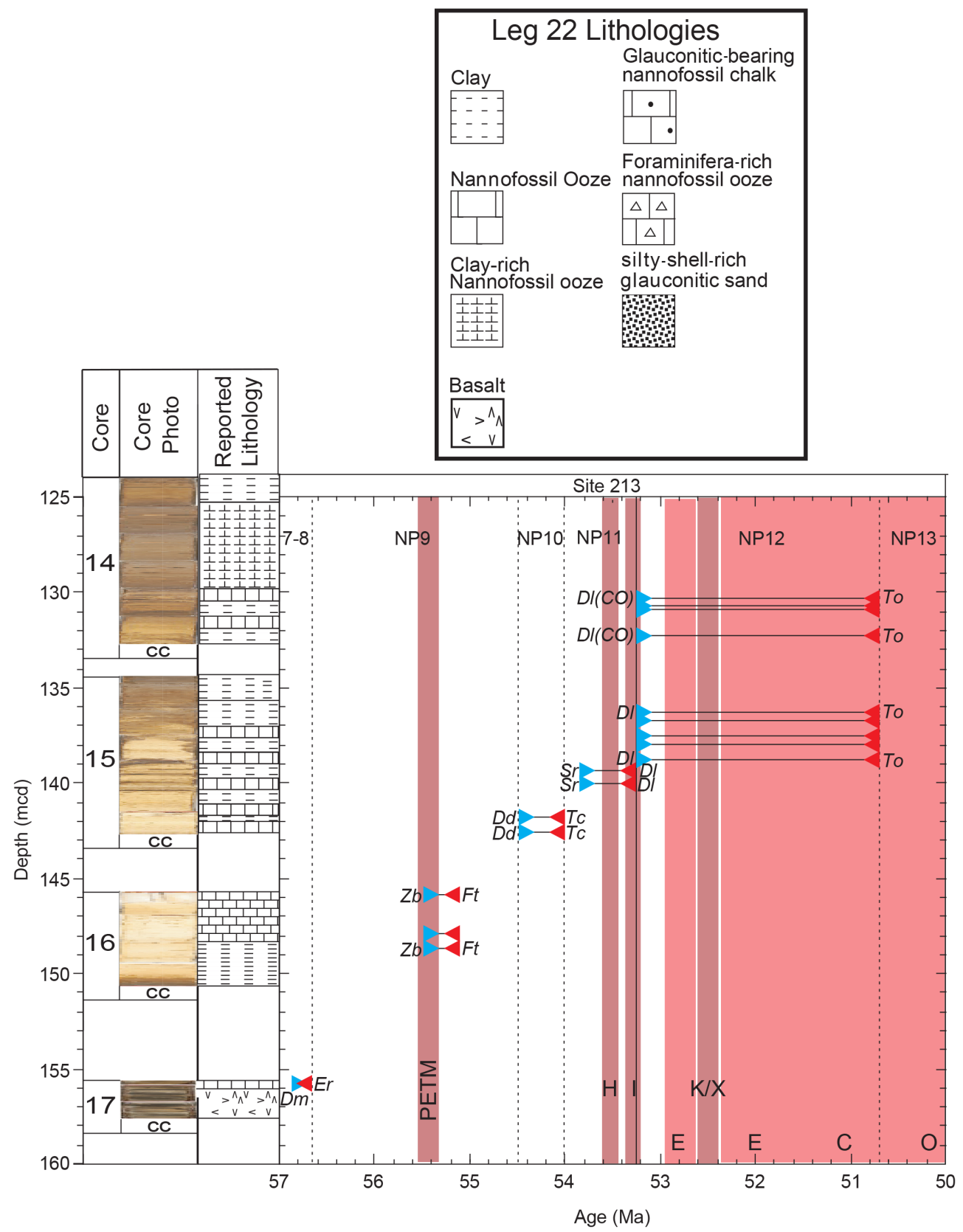

Figure 3. The depths of key nannofossil datums (bases - blue triangles; tops - red triangles) identified at Site 213. To and Dl indicate presence of both $T$. orthostylus and D. lodoensis. Dl and Sr indicate absence of D. lodensis and presence of $S$. radians. To and Dd indicate presence both of $T$. orthostylus and $D$. diastypus. Three samples marked $\mathrm{Ft}$ and $\mathrm{Zb}$ shows presence of both $F$. tympaniformis and Z. bijugatus, and dominance in abundance of Z. bijugatus over F. tympaniformis. Dm and Er indicate absence of D. multiradiatus and presence of E. robusta, according to Gartner (1974); data derived from sediment coated on basalt. Age estimates from Agnini et al. (2006, 2007) and calcareous nannofossil NP biozones from Martini (1971). Solid black vertical lines denote precisely known NP biozone boundaries; lines are dashed if boundary is not precisely known. Lithological facies key of core sections examined in this study located at top of figure.

from several processes (Ruddiman et al., 1987; Lisiecki and Herbert, 2007), also occur between successive rotary cores in unlithified ooze and clay, such as at Sites 213, 214, and 215.

To account for incomplete recovery within cores and probable gaps between cores, we follow procedures consis- tent with those used onboard more recent paleoceanography drilling expeditions. We assume incomplete core intervals always occur at the bottom of cores, and additional gaps between successive cores. We recast original depths onto a "meters composite depth" (mcd) scale. As we do not know 


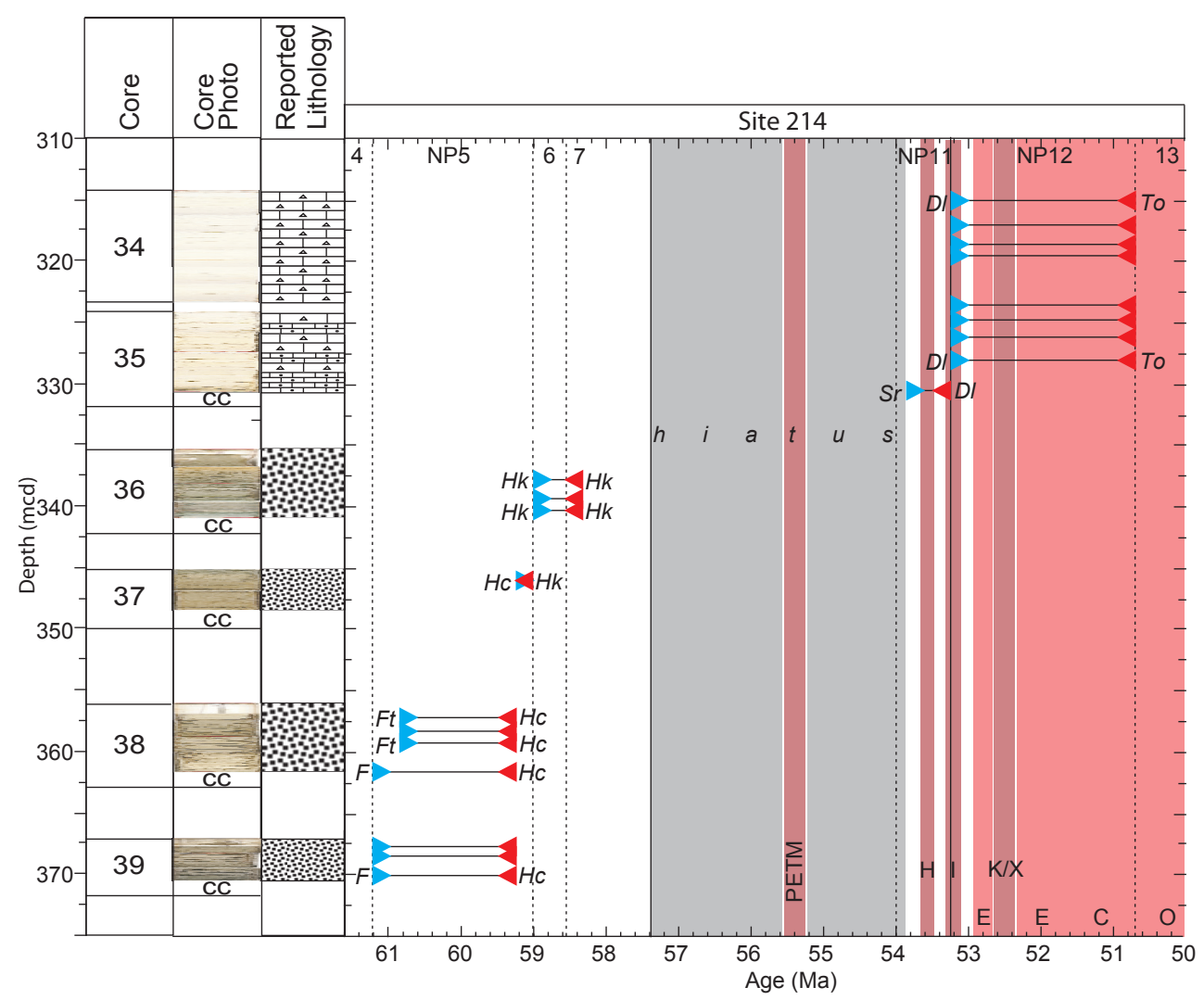

Figure 4. The depths of key nannofossil datums (bases - blue triangles; tops - red triangles) identified at Site 214 . To and Dl indicate presence of both $T$. orthostylus and D. lodoensis. D1 and Sr indicate absence of D. lodoensis and presence of $S$. radians. Hk indicates presence of $\mathrm{H}$. kleinpellii. $\mathrm{Hk}$ and $\mathrm{Hc}$ indicate absence of $\mathrm{H}$. kleinpellii and presence of $H$. cantabriae. Hc and Ft indicate absence of $H$. cantabriae and presence of $F$. tympaniformis. Hc and $\mathrm{F}$ indicate absence of $H$. cantabriae and presence of Fasciculithus spp. (poor preservation only permits recognition at the genus level). Age estimates from Agnini et al. (2006, 2007) and calcareous nannofossil NP biozones from Martini (1971). Solid black vertical lines denote precisely known NP biozone boundaries; lines are dashed if boundary is not precisely known. Note lithological facies key in Fig. 3.

the length of core gaps for Sites 213, 214, and 215, we assume they are $1 \mathrm{~m}$. This means there is always $\geq 1 \mathrm{~m}$ of sediment missing between successive cores (Figs. 3-5 and 7-9). Obviously, the $1 \mathrm{~m}$ length for the core gaps is arbitrary, but the inclusion of such gaps is important, as it identifies likely intervals of missing sediment. For further clarification on the matter of coring artifacts, Dickens and Backman (2013) present a lengthy discussion of the early Paleogene record at DSDP Site 577 on Shatsky Rise.

A total of three hundred ninety-five $10 \mathrm{~cm}^{3}$ early Paleogene sediment samples were taken from Sites 213, 214, and 215.

\subsection{Age model}

Throughout this work, we adhere to the astronomically tuned "Option 1" (WO-1) early Paleogene timescale (Westerhold et al., 2008). This is because multiple published and relevant data sets have been aligned to this timescale (Table 1). However, it is possible that the WO-1 timescale is offset by one
400 kyr eccentricity cycle near the late Paleocene (Hilgen et al., 2010; Vandenberghe et al., 2012).

\subsection{Sample preparation}

Each sample was freeze-dried and split into two aliquots: one for nannofossil examination, the other for geochemistry. The geochemistry aliquot was ground and homogenized using a glass mortar and pestle. Ground material of each sample was placed into a tube with $18 \mathrm{M} \Omega$ deionized water; mixed using a mini vortexer; and centrifuged for 10,15 , and $25 \mathrm{~min}$ sequentially to remove dissolved ions. Water was decanted after each interval of centrifuging. Centrifuged sample aliquots were then freeze-dried a second time.

\subsection{Nannofossil assemblages}

Calcareous nannofossils were investigated in 62 samples to refine the depths of biostratigraphic datums for chronological constraints. Smear slides were made following standard 


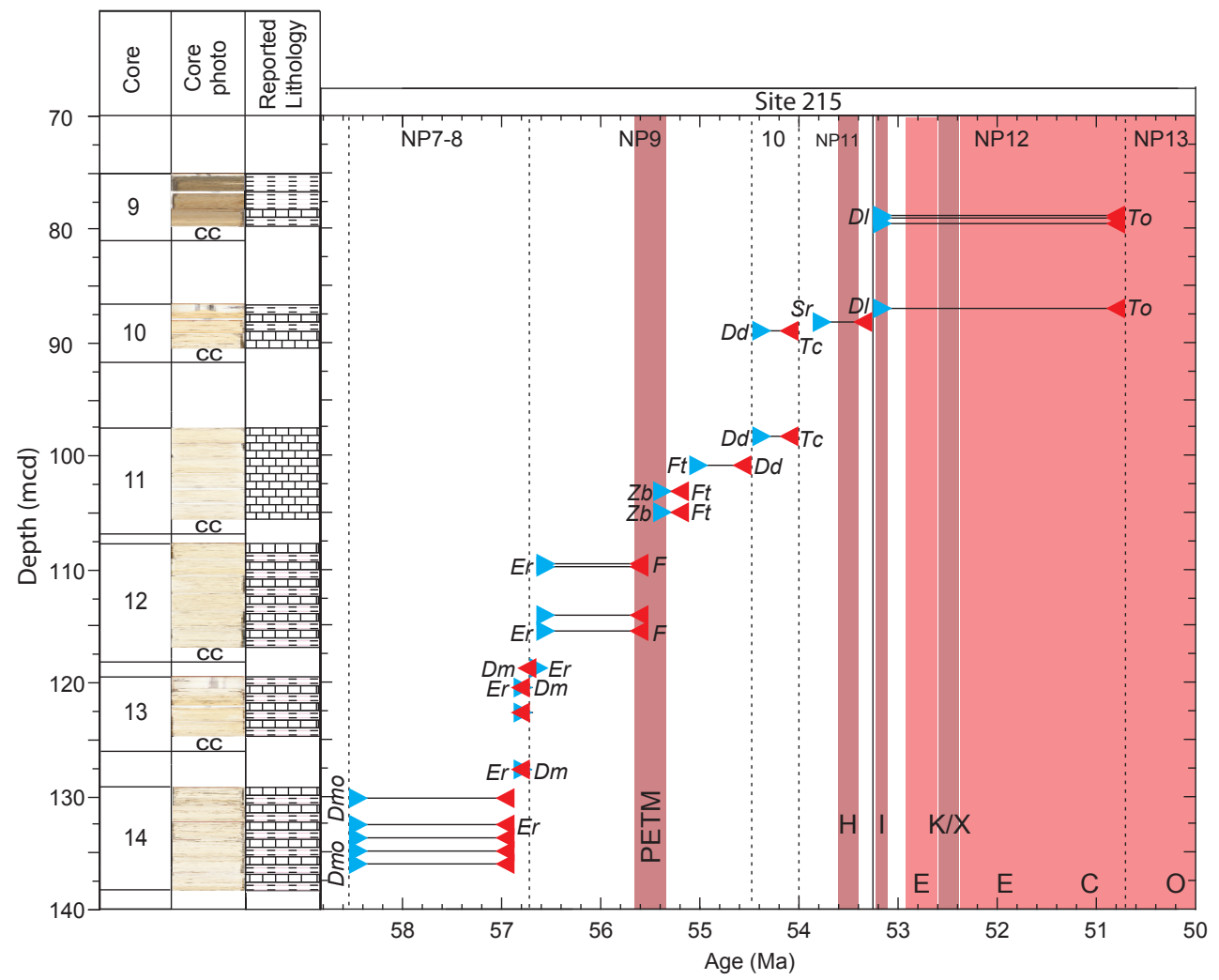

Figure 5. The depths of key nannofossil datums (bases - blue triangles; tops - red triangles) identified at Site 215. To and Dl indicate presence of both $T$. orthostylus and D. lodoensis. Dl and Sr indicate absence of D. lodoensis and presence of $S$. radians. Tc and Dd indicate presence of both $T$. contortus and $D$. diastypus. Dd and Ft indicate absence of $D$. diastypus and presence of a few to rare $F$. tympaniformis. The two samples marked $\mathrm{Ft}$ and $\mathrm{Zb}$ indicate presence of both F. tympaniformis and Z. bijugatus, and dominance in abundance of Z. bijugatus over F. tympaniformis. The four samples marked $\mathrm{F}$ and $\mathrm{Er}$ show presence of diverse and abundant Fasciculithus spp. and absence of $E$. robusta. Er and Dm indicate presence of both E. robusta and D. multiradiatus. Dm and Er indicate absence of D. multiradiatus and presence of E. robusta. The five samples marked Er and Dmo indicate absence of E. robusta and presence of D. mohleri. Age estimates from Agnini et al. $(2006,2007)$ and calcareous nannofossil NP biozones from Martini (1971). Solid black vertical lines denote precisely known NP biozone boundaries; lines are dashed if boundary is not precisely known. Note lithological facies key in Fig. 3.

methods. Estimates of abundance and preservation follow the guidelines outlined by Pälike et al. (2010). For the abundance of total nannofossils: D: dominant ( $>90 \%$ of total sediment grains); A: abundant (50-90\%); C: common (10-50\%); F: few $(1-10 \%)$; R: rare $(<1 \%)$; B: barren. For the preservation of nannofossils: G: good (little evidence of dissolution or recrystallization, primary morphological characteristics only slightly altered, specimens identifiable to the species level); M: moderate (specimens exhibit some etching or recrystallization, primary morphological characteristics somewhat altered, most specimens identifiable to the species level); P: poor (specimens severely etched or overgrown, primary morphological characteristics largely destroyed, fragmentation has occurred, specimens often not identifiable at the species or genus level).

A well-established sequence of appearances and disappearances of calcareous nannofossil species and genera spans the early Paleogene. These tops (T), bases (B), and evolution- ary crossovers $(\mathrm{X})$ have been calibrated to magnetic polarity chron boundaries at several sites (e.g., Agnini et al., 2007; Dickens and Backman, 2013). Some of these biohorizons have been used to construct calcareous nannofossil zonal schemes such as those of Okada and Bukry (1980) and Martini (1971), the latter of which we mention in this work. However, some datums for some species are not straightforward. For example, Discoaster lodoensis has a pulsed onset at several sites (Agnini et al., 2007; Dickens and Backman, 2013). As such, this species has a true base (B) as well as a higher position when the species begins to occur consistently and with high relative abundance (base common, or $\mathrm{Bc}$ ).

\subsection{Geochemistry}

Dried splits of bulk sediment samples were analyzed for carbonate content and stable isotope ratios at Utrecht University. Carbonate content was determined from the amount of carbon dioxide generated during combustion using a LECO 
Table 1. Paleomagnetic and nannofossil age estimates for the Paleocene and early Eocene.

\begin{tabular}{|c|c|c|c|c|c|}
\hline & Age datum & & $\begin{array}{l}\text { W-O1 } \\
\text { age [1] } \\
(\mathrm{Ma})\end{array}$ & $\begin{array}{l}\text { GPTS } 2004 \\
\text { age [2] } \\
(\mathrm{Ma})\end{array}$ & $\begin{array}{l}\text { Zone } \\
\text { base }\end{array}$ \\
\hline $\mathrm{N}$ & Base & Discoaster sublodoensis & 49.5 & & NP14 \\
\hline $\mathrm{N}$ & Top & Tribrachiatus orthostylus & 50.7 & & \\
\hline $\mathrm{E}$ & Base & $\mathrm{K} / \mathrm{X}$ hyperthermal & 52.50 & & \\
\hline $\mathrm{N}$ & Base & Discoaster lodoensis & 53.24 & 53.11 & NP12 \\
\hline $\mathrm{N}$ & Top & Discoaster multiradiatus & 53.24 & 53.11 & \\
\hline $\mathrm{E}$ & Base & ETM2/H1 hyperthermal & 53.73 & & \\
\hline $\mathrm{N}$ & Top & Tribrachiatus contortus & 53.80 & 53.49 & \\
\hline $\mathrm{N}$ & Base & Sphenolithus radians & 53.85 & 53.53 & \\
\hline $\mathrm{N}$ & Base & Tribrachiatus orthostylus & 54.00 & 53.67 & NP11 \\
\hline $\mathrm{N}$ & Base & Tribrachiatus contortus & 54.34 & 54.00 & \\
\hline $\mathrm{N}$ & Base & Discoaster diastypus & 54.48 & 54.13 & NP10 \\
\hline $\mathrm{N}$ & Top & Fasciculithus spp. & 55.11 & 54.71 & \\
\hline $\mathrm{N}$ & & Fasciculithus decrease diversity & 55.47 & & \\
\hline $\mathrm{N}$ & Crossover & Zygrhablithus bijugatus/Fasciculithus tympaniformis & 55.47 & & \\
\hline $\mathrm{E}$ & Base & PETM hyperthermal & 55.53 & 55.00 & \\
\hline $\mathrm{N}$ & Top & Ericsonia robusta & 56.66 & & \\
\hline $\mathrm{N}$ & Base common & Discoaster multiradiatus & 56.76 & 56.01 & NP9 \\
\hline $\mathrm{N}$ & Top & Discoaster okadai & 56.85 & 56.12 & \\
\hline $\mathrm{N}$ & Base & Discoaster okadai & 56.95 & 56.23 & \\
\hline $\mathrm{N}$ & Base & Discoaster nobilis & 56.97 & 56.25 & \\
\hline $\mathrm{N}$ & Base & Ericsonia robusta & 57.04 & & \\
\hline $\mathrm{N}$ & Top & Heliolithus kleinpellii & 58.33 & 57.42 & \\
\hline $\mathrm{N}$ & Base & Discoaster mohleri & 58.55 & 57.57 & NP7 \\
\hline $\mathrm{N}$ & Top & Heliolithus cantabriae & 58.64 & & \\
\hline $\mathrm{N}$ & Base & Heliolithus kleinpellii & 59.02 & 58.03 & NP6 \\
\hline $\mathrm{N}$ & Base & Heliolithus cantabriae & 59.37 & & \\
\hline $\mathrm{N}$ & Base & Fasciculithus tympaniformis & 60.9 & & \\
\hline $\mathrm{N}$ & Base & Fasciculithus spp. & 61.21 & 60.31 & NP5* \\
\hline $\mathrm{N}$ & Base & Sphenolithus spp. & 61.59 & 60.74 & \\
\hline
\end{tabular}

Notes: [1] ages to the nearest 0.1 Ma as reported by Agnini et al. (2007) and Westerhold et al. (2008); W-O1: Westerhold Option 1; N: nannofossil datum; E: Carbon Isotope Excursion datum. [2] GPTS 2004. Ages slightly differ between papers (e.g., Agnini et al., 2007, and Westerhold et al., 2008) * The actual NP5 start is for F. tympanformis at ca. 60.9 Ma.

SC-632 analyzer. Each sample was weighed, and calculations incorporated these masses. Multiple analyses of the WEPAL-ISE 983 and in-house carbonate standards form the basis for accuracy and precision $(0.8 \%$ at $1 \sigma)$. Stable carbon and oxygen isotopes were determined using an ISOCARB common acid bath carbonate preparation device linked to a VG24 SIRA mass spectrometer. Instrumental calibrations were constrained using in-house standards IAEA-CO- 1 and NAXOS (Coplen et al., 2006). Ratios were converted to standard delta notation relative to Vienna Pee Dee Belemnite (VPDB). Analytical precision was $0.05 \%$ at $1 \sigma$ and $0.10 \%$ at $2 \sigma$ for $\delta^{13} \mathrm{C}$ and $\delta^{18} \mathrm{O}$, respectively. Although all samples were analyzed for stable isotopes, 37 samples from Site 213 and 20 samples from Site 215 did not give accurate values because they have very low $(<5 \%)$ carbonate contents.

\section{Results}

\subsection{Nannofossil assemblages and age control}

The intervals investigated span the Paleocene-Eocene boundary, from Zone NP7-8 to Zone NP12 (Site 213), Zone NP4-5 to Zone NP12 (Site 214) and Zone NP7-8 to Zone NP12 (Site 215) in the biozonation of Martini (1971). The Paleocene-Eocene boundary, however, is lost in core gaps at all three sites. Gartner (1974) and Bukry (1974) originally investigated calcareous nannofossils at these sites. The data produced here are consistent with their findings. Assemblages are mostly poorly preserved (Tables $2-4$ ).

Based on presence and absence of selected taxa, a minimum and maximum age can be assigned to each sample. Age estimates of calcareous nannofossil biohorizons are from Agnini et al. (2006, 2007), placed on an updated timescale (Option 1; Westerhold et al., 2008; Table 1). 

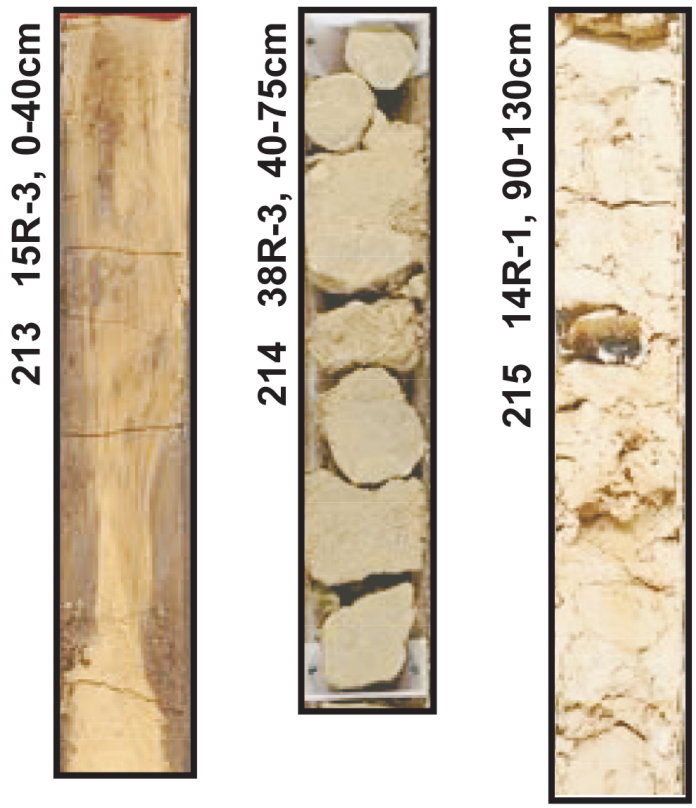

Figure 6. Core photos of disturbed sediment intervals recovered at each of the sites examined. When drilled in 1972, the sites were cored using rotary methods. As a result, there is considerable drilling disturbance over certain intervals.

The following biochronologic constraints were used for determining age relationships at Site 213. A sample showing an overlap in the ranges of Tribrachiatus orthostylus and Discoaster lodoensis indicates that the sample must be older than $50.70 \mathrm{Ma}$, which is the estimate for the top of $T$. orthostylus (base of Zone NP13). This estimate thus represents the youngest possible (minimum) age for the sample. Similarly, the oldest possible age for the sample must be the base of D. lodoensis (base of Zone NP12), occurring at 53.24 Ma.

Samples below the range of $D$. lodoensis and showing the presence of Sphenolithus radians indicate Zone NP 11, and a minimum age of $53.24 \mathrm{Ma}$ (sample older than base D. lodoensis), and a maximum age of $53.85 \mathrm{Ma}$ (sample is younger than appearance age of $S$. radians). Samples below the range of T. orthostylus and showing presence of Discoaster diastypus indicate Zone NP10, a minimum age of $54.00 \mathrm{Ma}$ and a maximum age of 54.48 Ma. Samples showing an overlap in range between Zygrhablithus bijugatus and Fasciculithus tympaniformis, and in which the former dominates in abundance over the latter, range in age from 55.11 to $55.47 \mathrm{Ma}$.

Gartner (1974) mark an overlap in range between Ericsonia robusta and Discoaster multiradiatus in sample 213$17-1,120 \mathrm{~cm}$, indicating Zone NP9 and an age range from $56.66 \mathrm{Ma}$ (top E. robusta) to $56.76 \mathrm{Ma}$ (base D. multiradiatus, and the base of NP9). This suggests that the onset of the PETM (i.e., the Paleocene-Eocene boundary) is missing within a gap between cores 213-16 and 213-17.
Similar information was used to constrain ages at Site 214 The simultaneous presence of $D$. lodoensis and $S$. radians was observed in a single sample (214-35-4, 140-142 cm), and indicates an age between 53.24 and $53.85 \mathrm{Ma}$. The next deeper sample (214-36-2, 120-122 cm) holds an upper Paleocene assemblage including Heliolithus kleinpellii. The appearance of this species defines the base of Zone NP6 (59.02 Ma), and its disappearance is calibrated to $58.33 \mathrm{Ma}$, which is within the combined Zone NP7-NP8 (see Agnini et al., 2007). Absence of $\mathrm{H}$. kleinpellii and presence of Heliolithus cantabriae suggests Zone NP5 and an age range between $59.02 \mathrm{Ma}$ (older than base H. kleinpellii) and $59.37 \mathrm{Ma}$ (younger than base $H$. cantabriae). Absence of $H$. cantabriae and presence of $F$. tympaniformis indicates an age range from $59.37 \mathrm{Ma}$ (older than base H. cantabriae) to $60.90 \mathrm{Ma}$ (younger than base $F$. tympaniformis). Preservation is too poor in lower Core 214-38 and Core 214-39 to judge whether or not $F$. tympaniformis is present. However, rare specimens of Fasciculithus spp. were present, indicating a maximum age of $61.21 \mathrm{Ma}$ (younger than base Fasciculithus spp.).

Based on these data, Site 214 has a significant hiatus. Although the duration cannot be precisely determined (because of missing sediment), the hiatus probably represents time from 53.85 to $58.33 \mathrm{Ma}$.

Biostratigraphic data used to provide age ranges of samples at Site 215 are as above in the NP10 through NP12 interval. The Paleocene-Eocene boundary is missing within a gap between cores 215-11 and 215-12. In cores below, diverse and abundant Fasciculithus spp. indicate an age older than $55.53 \mathrm{Ma}$. Absence of E. robusta indicates an age younger than 56.66 Ma. Overlap in the ranges between E. robusta and Discoaster multiradiatus indicates a minimum age of 56.66 Ma (top E. robusta) and a maximum age of $56.76 \mathrm{Ma}$ (base D. multiradiatus). Absence of D. multiradiatus and presence of E. robusta indicates a minimum age of $56.76 \mathrm{Ma}$ (base D. multiradiatus) and a maximum age of $57.04 \mathrm{Ma}$ (base $E$. robusta). These biostratigraphic data suggest the upper part of the combined Zone NP7-NP8. Absence of E. robusta and presence of Discoaster mohleri indicates a minimum age of $57.04 \mathrm{Ma}$ (base E. robusta) and a maximum age of $58.55 \mathrm{Ma}$ (base D. mohleri), within the lower part of combined Zone NP7/NP8.

\subsection{Carbonate content}

Carbonate content measurements at Site 213 (Table 5) render a complex curve (Fig. 7). Values are $<2 \%$ and average $1 \%$ from the top of section 13-1 through the bottom of section $14-4$ (113.8-129.8 mcd). Starting near the top of section 145 , carbonate contents increase significantly, reaching $73 \%$ by $132.8 \mathrm{mcd}$. A prominent low in carbonate content, where values drop to about $2 \%$, marks the top of Core 15 (134.5$135.5 \mathrm{mcd}$ ). Over the next $7.6 \mathrm{~m}$, carbonate content generally increases, although with two short intervals of relatively low values, centered at 135.6 and 139.5 mcd. From 139.9 


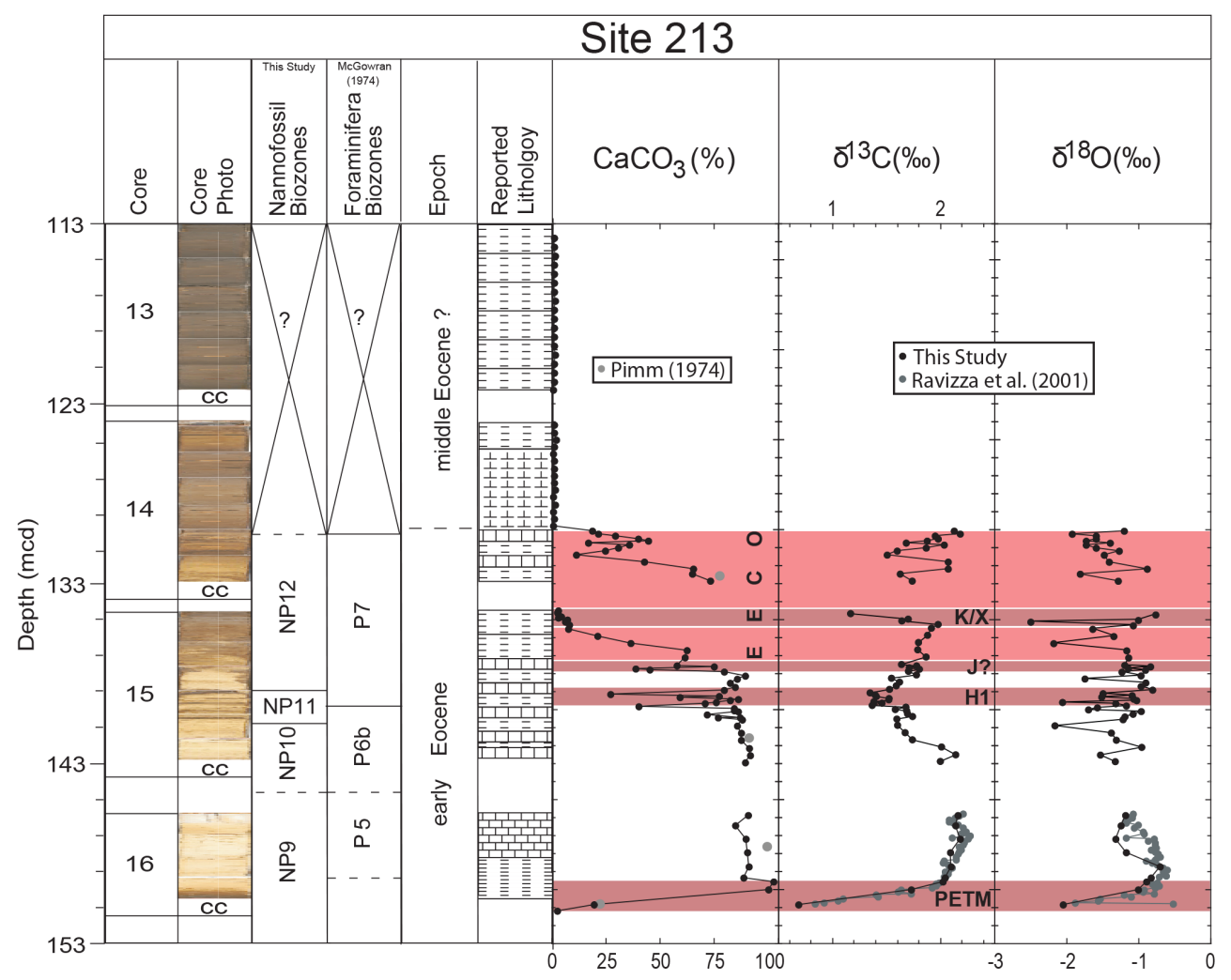

Figure 7. Early Paleogene sequences at DSDP Site 213. Biostratigraphy and lithology have been modified from the DSDP Leg 22 volume (von der Borch and Sclater, 1974). Core photos are sourced from the online database (www.iodp.org). Bulk carbonate $\delta^{13} \mathrm{C}$ and $\delta^{18} \mathrm{O}$ records near the base of Core 16 include data from previous work spanning the PETM recovery (grey - Ravizza et al., 2001). Carbonate content records include data from previous work (grey - Pimm, 1974). Consistent with the K/X event occurring near the NP11-NP12 zonal boundary (Agnini et al., 2007), the H, J, and onset of K/X events occur in Core 15 sections 15-4, 15-3, and 15-1, respectively. The H and I events may have been mixed together since rotary coring was used for core collection. The upper portion of core 15 and all of core 14 likely spans the EECO, as indicated by depleted $\delta^{13} \mathrm{C}$ and key zonal boundaries. Calcareous nannofossil NP biozones from Martini (1971) and foraminiferal P biozones from Berggren et al. (1995). Note lithological facies key in Fig. 3.

to $149.3 \mathrm{mcd}$, carbonate content is generally high, ranging between 85 and $91 \%$. Importantly, moderate nannofossil preservation spans this interval of high carbonate content. The core catcher of section 16 has very low carbonate content.

Carbonate content data at Site 214 (Table 6) also results in a complex profile (Fig. 8). Values are $>91 \%$ and average $93 \%$ from the top of section 34-1 through the top of section 35-1 (314.6-324.5 mcd). Starting near the top of section $35-1$, carbonate contents decrease slightly, reaching $85 \%$ by $329.6 \mathrm{mcd}$. A further decrease in carbonate contents spans the base of sections $35-4$ and $35-\mathrm{cc}$, where values drop to $74 \%$ at $330.7 \mathrm{mcd}$. Beginning at $336.1 \mathrm{mcd}$ and for the next $34.7 \mathrm{~m}$ downcore, carbonate contents generally fluctuate between 4 and $65 \%$, and average $37 \%$.

Carbonate content measurements at Site 215 (Table 7) contrast with the other two sites: except for a transition interval, they are either very low or very high, depending on past water depth (Fig. 9). Values are $<3 \%$ and average $1 \%$ from the top of section 8-1 through the middle of section 9-3
(65.4-78.6 mcd). Starting in section 9-3, carbonate contents increase significantly, reaching $93 \%$ by 87.9 mcd. Over the next $48.5 \mathrm{~m}$, carbonate content is universally high, ranging between 82 and $97 \%$. As at Site 213, moderate nannofossil preservation spans the interval of particularly high carbonate content, although, in general, carbonate content at Site 215 is higher than at Site 213. The lowest values within this interval are centered at $119.6 \mathrm{mcd}$.

Prior to our work, several analyses of carbonate content were conducted at these sites as part of DSDP Leg 22 operations (Pimm, 1974). Most samples from the two studies appear to be within $5 \%$ (Figs. 7-9), although a rigorous comparison cannot be made because of slight differences in depth between samples.

\subsection{Carbon isotopes}

Bulk carbonate $\delta^{13} \mathrm{C}$ values at Site 213 (Table 5) have a complicated profile (Fig. 7). Samples at the top of the studied section $(113.8-130.1 \mathrm{mcd})$ have too little carbonate for reliable 


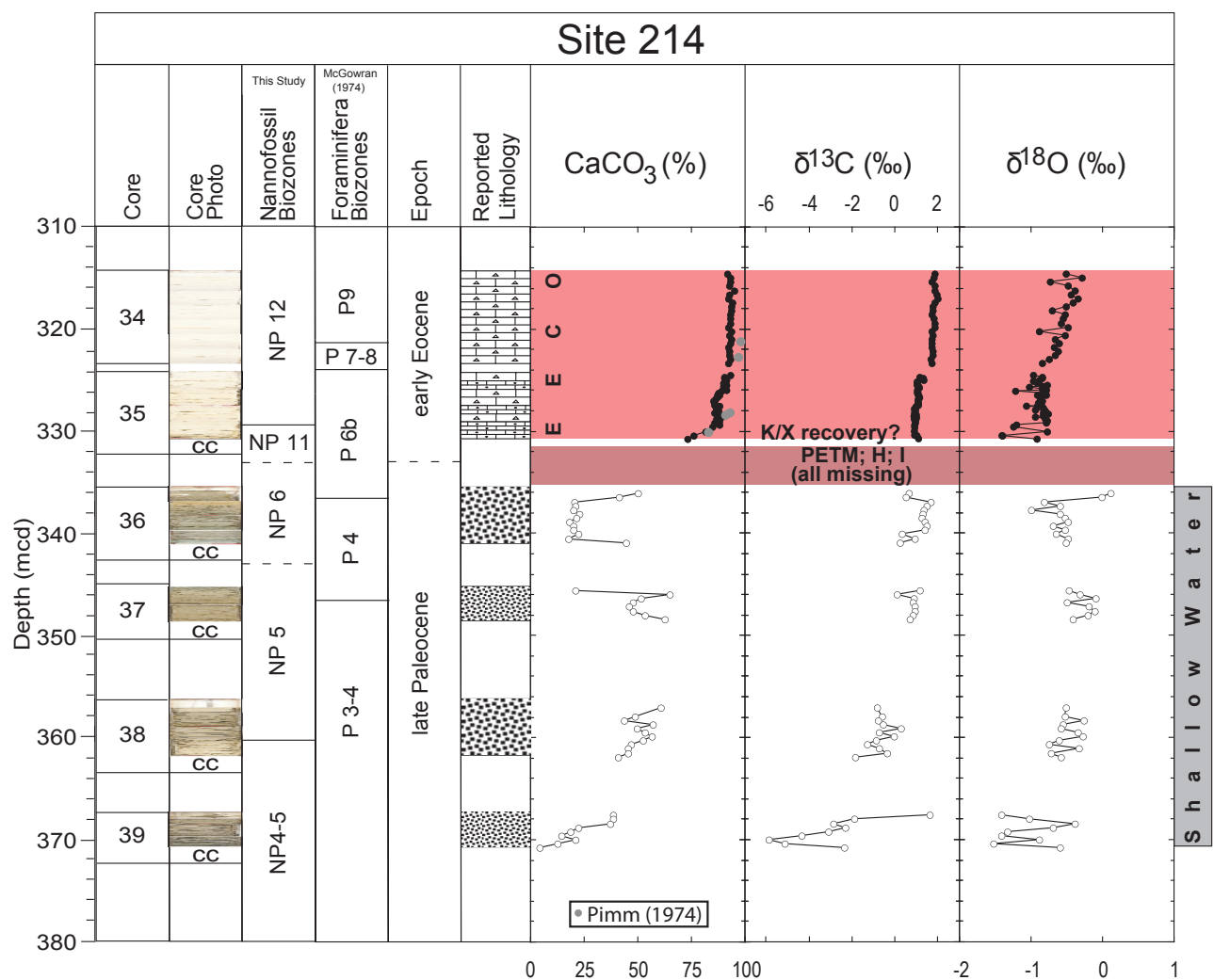

Figure 8. Early Paleogene sequences at DSDP Site 214. Biostratigraphy and lithology have been modified from the DSDP Leg 22 volume (von der Borch and Sclater, 1974). Core photos are sourced from the online database (www.iodp.org). Carbonate content records include data from previous work (grey - Pimm, 1974). Numerous hyperthermals, including the PETM, H events, I events, and K/X, are missing in the hiatus in the core gap between cores 36 and 35. It is possible that the uppermost recovery interval of the K/X event spans the base of core 35, where already elevated carbonate contents increase slightly. Calcareous nannofossil NP biozones from Martini (1971) and foraminiferal P biozones from Berggren et al. (1995). Note lithological facies key in Fig. 3.

stable isotope analyses. From the top of section 14-5 through the base of section 14-6 (130.1-132.8 mcd), values range between 1.50 and $2.18 \%$ and average $1.87 \%$. A prominent low in bulk carbonate $\delta^{13} \mathrm{C}$, with values reaching $1.17 \%$, marks the top of Core 15 (134.7-135.3 mcd). Over the next $3.8 \mathrm{~m}$, bulk carbonate $\delta^{13} \mathrm{C}$ generally decreases, culminating in a pronounced low between 139.1 and 139.8 mcd. This is followed below by a general rise through the base of section $15-6$. From 145.8 to $149.5 \mathrm{mcd}$, bulk carbonate $\delta^{13} \mathrm{C}$ is generally high, but decreases gradually from 2.27 to $2.02 \%$. This drop in $\delta^{13} \mathrm{C}$ intensifies through sections $16-4$ and 16-cc, as also found by Ravizza et al. (2001), such that a prominent negative CIE of at least $1.4 \%$ exists.

Bulk carbonate $\delta^{13} \mathrm{C}$ values at Site 214 (Table 6) generally decrease with greater depth (Fig. 8). However, the low $\delta^{13} \mathrm{C}$ values measured in cores 36 through 39-3 are noteworthy, because they cannot represent primary pelagic carbonate. These samples accumulated during the middle Paleocene (as some contain H. kleinpellii or H. cantabriae) but clearly contrast with the $\delta^{13} \mathrm{C}$ composition of pelagic carbonate from this time interval. The anomalous $\delta^{13} \mathrm{C}$ may be consistent with neritic carbonate. Shallow marine carbonate exhibits a wide range in $\delta^{13} \mathrm{C}$ composition (cf. Swart and Eberli, 2005) and can be significantly depleted in ${ }^{13} \mathrm{C}$ when they precipitate in exchange with pore waters that have a high contribution of $\Sigma \mathrm{CO}_{2}$ from organic carbon respiration (Patterson and Walter, 1994a, b; Sanders, 2003). We have not investigated this possibility further, but the interval at Site 214 provides an interesting example of where carbon isotope stratigraphy does not work.

Bulk carbonate $\delta^{13} \mathrm{C}$ measurements at Site 215 (Table 7) give a fairly straightforward curve (Fig. 9). As at Site 213, uppermost samples (65.4 to $78.6 \mathrm{mcd}$ ) contain too little carbonate to yield reliable bulk carbonate $\delta^{13} \mathrm{C}$ values. Near the base of section $9-3$, values range between 1.71 and $2.03 \%$. Values then drop to $1.08 \%$ at the top of section $10-1$. Over the next $28.8 \mathrm{~m}$, bulk carbonate $\delta^{13} \mathrm{C}$ generally rises, reaching $\sim 3.5 \%$ in the base of section $12-6(115.4 \mathrm{mcd})$. From 118.2 to $136.4 \mathrm{mcd}$, bulk carbonate $\delta^{13} \mathrm{C}$ is generally high. Except for a few relatively slight drops in $\delta^{13} \mathrm{C}$, one located within section $13-2$, from 119.1 to $119.6 \mathrm{mcd}$, values exceed $3 \%$ in lower cores at Site 215. 


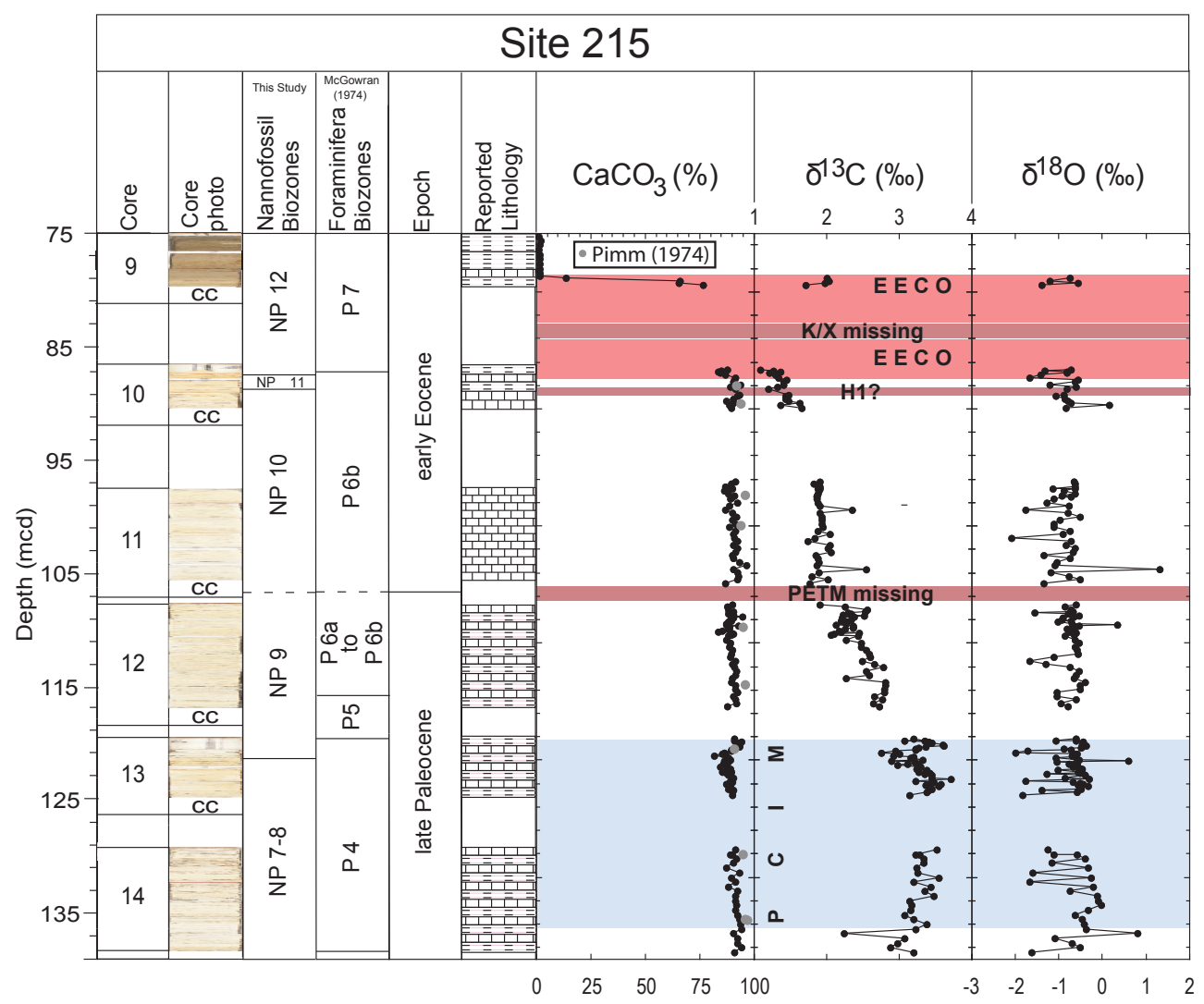

Figure 9. Early Paleogene sequences at DSDP Site 215. Biostratigraphy and lithology have been modified from the DSDP Leg 22 volume (von der Borch and Sclater, 1974). Core photos are sourced from the online database (www.iodp.org). Carbonate content records include data from previous work (grey - Pimm, 1974). Enriched $\delta^{13} \mathrm{C}$ and biozonations enabled the identification of the PCIM in cores 14-13. Calcareous nannofossil NP biozones from Martini (1971) and foraminiferal P biozones from Berggren et al. (1995). The PETM is in the core gap between cores 12 and 11, consistent with the presence of the P5 foraminiferal biozone. The H events are either in the core gap between cores 11 and 10 or represented by $\delta^{13} \mathrm{C}$ drop from 88.787 to $88.29 \mathrm{mcd}$. The NP11 and NP12 biozones and depleted $\delta^{13} \mathrm{C}$ enabled the EECO identification in upper portion of core 10. The K/X event is in the core gap between cores 10 and 9. Note lithological facies key in Fig. 3.

\subsection{Oxygen isotopes}

Bulk carbonate $\delta^{18} \mathrm{O}$ measurements (Tables 5-7) yield records with noteworthy trends (Figs. 7-9). At Site 213, from the top of section 14-5 to the base of section 15-6, values vary between -2.5 and $-0.8 \%$. Below, bulk carbonate $\delta^{18} \mathrm{O}$ rises slightly from -1.2 to $-0.6 \%$, and then drops significantly, reaching $-1.9 \%$ at $157.7 \mathrm{mcd}$. At Site 214 , values range between -1.5 and $0.1 \%$. There is a general decrease with depth through cores 34 and 35 . In underlying sediment, bulk carbonate $\delta^{18} \mathrm{O}$ increases to $0.0 \%$ in core 37 and then decreases. At Site 215, values vary between -2.1 and $1.3 \%$. There is a slight overall increase in bulk carbonate $\delta^{18} \mathrm{O}$ with increasing depth.

\section{Discussion}

\subsection{Overview}

The reconstruction of a "paleo-CCD curve" for an ocean basin requires key information from multiple sites (e.g., van Andel, 1975; Pälike et al., 2012). At a given site, these are (1) the age of the sediment deposited, (2) the depth trajectory through time, and (3) the carbonate accumulation overlain upon this trajectory.

\subsection{Revised age models}

Our calcareous nannofossil biostratigraphic data provide internally consistent age constraints at all three sites and support the presence of core gaps. Although moderate to poor preservation impacts precise placement of key nannofossil datums (tops and bases of index species), depth horizons can be assigned age ranges (Figs. 3-5). Such age constraints are broadly compatible with previous literature concerning 


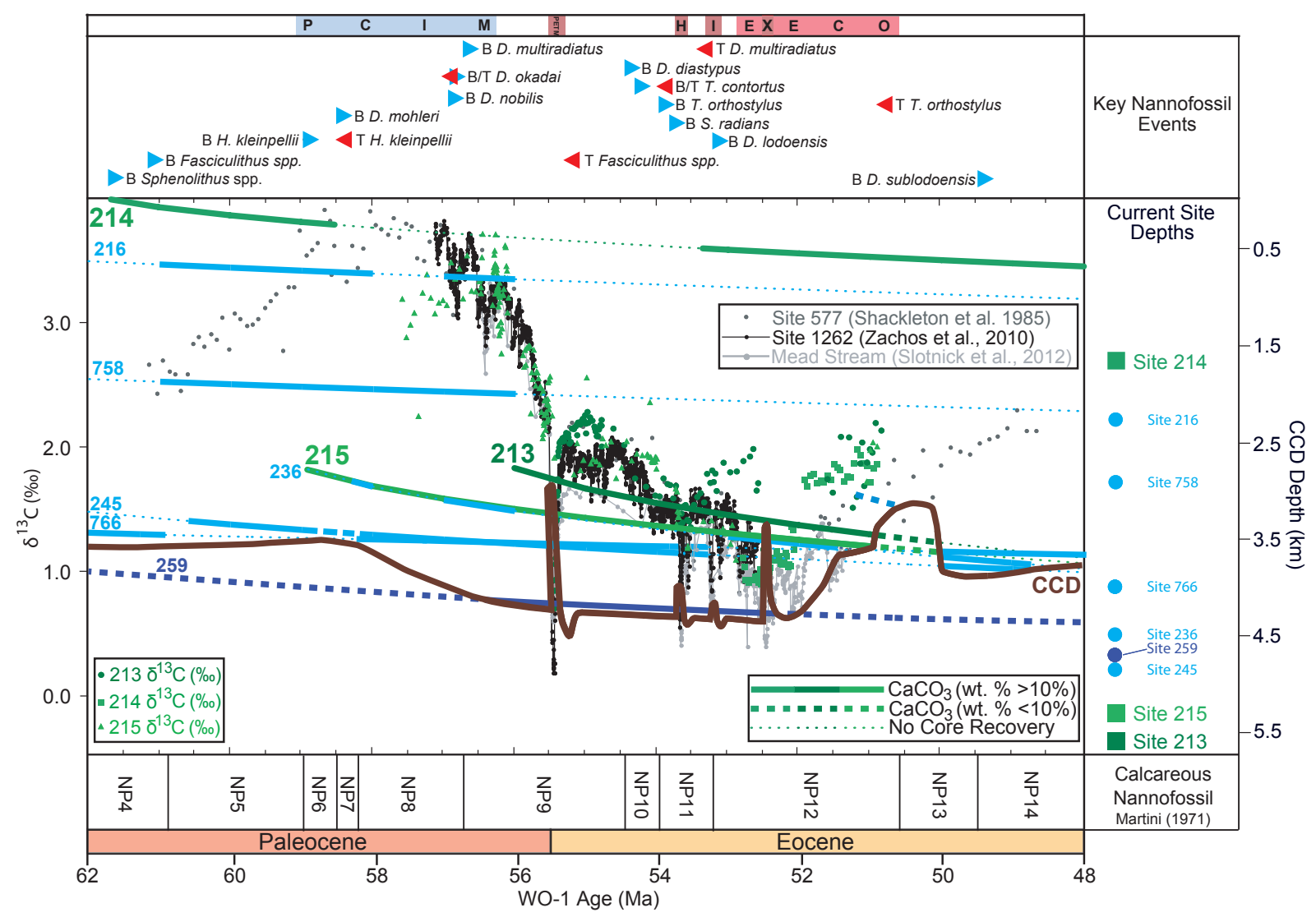

Figure 10. Bulk carbonate $\delta^{13} \mathrm{C}$ records and calcareous intervals for several locations placed onto a current timescale (Option 1; Westerhold et al., 2008). Stable isotope records include those at DSDP Site 577 (North Pacific; Shackleton et al., 1985), ODP Site 1262 (central Atlantic; Zachos et al., 2010) and Mead Stream (South Pacific; Slotnick et al., 2012). Subsidence curves for Sites 213 and 215 (various shades of green) and for Sites 236, 245, and 766 (Shipboard Scientific Party, 1974b; Shipboard Scientific Party, 1974c; Shipboard Scientific Party, 1990 light blue) were calculated using a slightly modified version of the mid-ocean ridge subsidence curve from Rea and Lyle (2005). Subsidence curves for Site 214 (green) and for Sites 216 and 758 (Shipboard Scientific Party, 1974a; Shipboard Scientific Party, 1989c - light blue) follow established guidelines for aseismic ridges (Detrick et al., 1977). Plotted curves, when solid, indicate carbonate contents $>10 \%$, but when dashed they indicate carbonate contents $<10 \%$. Importantly, curves are lightly dotted when no data are available. The dark-brown solid line denotes reconstructed CCD following new carbonate content data. The biozonal scheme adopted is that of Martini (1971). Ages of calcareous nannofossil biohorizons are those proposed by Agnini et al. (2006, 2007) recalibrated using Option 1 of Westerhold et al. (2008).

microfossils in lower Paleogene sediment from these sites, as long as datums are placed on current timescales (Table 1). This includes work on calcareous nannofossils (Gartner, 1974; Bukry, 1974; Tremolada and Bralower, 2004), as well as planktic foraminifera (McGowran, 1974; Berggren and Norris, 1997; Hovan and Rea, 1992).

Using biostratigraphic information presented here (Figs. 3-5), million-year sedimentation rates across carbonate-rich intervals at Sites 213 and 215 (the abyssal sites) averaged between 0.4 and $0.9 \mathrm{~cm} \mathrm{kyr}^{-1}$. Those at Site 214 (the shallow ridge crest location) may have approached $2 \mathrm{~cm} \mathrm{kyr}^{-1}$ for intervals of the early Paleogene, but the overall record contains a major hiatus. We note that such calculated rates pertain to sediment that has been compacted, albeit minimally given the modest burial depth (and this lowers sedimentation rates relative to those at the seafloor); on the other hand, such rates pertain to an mod depth scale (and this raises sedimentation rates relative to those at the seafloor). In any case, early Paleogene sedimentation in the region was very slow, particularly at Sites 213 and 215. Such rates are consistent with those at sites on the flanks of the East Pacific Rise during the early Paleogene (Leon-Rodriguez and Dickens, 2010).

The occurrence of E. robusta at Site 215 warrants brief discussion. This calcareous nannoplankton species existed for approximately 0.4 Myr (Agnini et al., 2007). Given longterm sedimentation at Site $215\left(0.9 \mathrm{~m} \mathrm{Myr}^{-1}\right)$, E. robusta should span about $3.6 \mathrm{~m}$. According to our data, however, this nannofossil occurs over about $9.1 \mathrm{mcd}$ (Table 4), which includes at least $3 \mathrm{~m}$ of missing section and a presumed $1 \mathrm{~m}$ gap between the bottom of core 13 and the top of core 14 (Fig. 5). We do not know whether this signifies that core is 
missing from the top of core 13 (rather than the bottom), that the gap between cores is less than $1 \mathrm{~m}$, that the interval had a high sedimentation rate, or some combination of these.

Characteristic features of early Paleogene $\delta^{13} \mathrm{C}$ curves can be used for stratigraphic purposes (e.g., Shackleton, 1986; Slotnick et al., 2012). Although the $\delta^{13} \mathrm{C}$ records at Sites 213, 214 , and 215 are not ideal, because of core gaps, drilling disturbance, and hiatuses, key features can be identified. The prominent high in $\delta^{13} \mathrm{C}$ during the PCIM and the subsequent $5 \mathrm{Myr}$ decrease in $\delta^{13} \mathrm{C}$ toward the EECO is found at Site 215. The $\delta^{13} \mathrm{C}$ rise during and following the EECO is found at Site 214. At least two short-term CIEs can be found at Site 213. Indeed, once the $\delta^{13} \mathrm{C}$ records at the three sites are spliced together in the time domain, and once intervals of missing sediment are accounted for, reasonable alignment with other marine $\delta^{13} \mathrm{C}$ records emerges (Fig. 10).

\subsection{Site subsidence trajectories}

The water depth of tholeiitic basalt formed at a mid-ocean ridge younger than $70 \mathrm{Ma}$ can be predicted using subsidence curves (Sclater et al., 1971; Berger, 1972; van Andel, 1975). For Sites 213 and 215, basalt emplacement clearly occurred at a ridge axis $<70 \mathrm{Ma}$ (most likely the SEIR), as also indicated by metalliferous ooze mixed with pelagic calcareous organisms in basal sediments (von der Borch and Sclater, 1974). A generic subsidence equation for such sites is (Parsons and Sclater, 1977)

$z=z_{(\mathrm{o})}+C t^{1 / 2}$,

where $z$ is the present meters below sea level ( $\mathrm{m} \mathrm{b.s.l.)}, z_{(\mathrm{o})}$ is depth of the ridge at initial time (m b.s.l.), $C$ is the subsidence rate $\left(\mathrm{m} \mathrm{Myr}^{-1}\right)$, and $t$ is time since formation (Ma). Because porous sediment adds mass on top of the basalt but is about half the density, it should be accounted for (Rea and Lyle, 2005). A simple correction is (Berger, 1973; Rea and Lyle, 2005)

$z=\left(z_{(\mathrm{o})}+C t^{1 / 2}\right)-0.5 z_{(\mathrm{s})}$,

where $z_{(\mathrm{s})}$ is the thickness of overlying sediment (m).

As noted for CCD reconstructions in the eastern Pacific (Leon-Rodriguez and Dickens, 2010; Pälike et al., 2012), two problems exist in such depth reconstructions. First, water depths range significantly along the crest of modern midocean ridges (e.g., Cochran, 1986; Calcagno and Cazenave, 1994). For the crest of the modern SEIR, they range from 2500 to $3300 \mathrm{~m}$ b.s.l., and generally deepen to the southeast (Cochran, 1986; Mahoney et al., 2002). This range of "zeroage" depths probably reflects differences in mantle properties below the ridge crest, perhaps including a drop in upper mantle temperatures to the east (Cochran, 1986; Klein et al., 1991; Mahoney et al., 2002). Second, subsidence rates along mid-ocean ridges vary significantly (e.g., Cochran, 1986; Calcagno and Cazenave, 1994). For the SEIR, they vary from
200 to $460 \mathrm{~m} \mathrm{Myr}^{-1 / 2}$, with some of this variance related to the presence of fracture zones (Cochran, 1986). Together, these heterogeneities add uncertainty to subsidence curve estimates (Leon-Rodriguez and Dickens, 2010). It is important to recognize, though, that the maximum uncertainty in past depth generally occurs when the site is at or near the ridge crest, because subsidence decays exponentially over time (Eq. 1).

When discussing crustal subsidence in the southern Indian Ocean, Cochran (1986) noted a generally symmetric bathymetric profile along the SEIR between 90 and $96^{\circ}$ E latitude. $\mathrm{He}$ further suggested a subsidence rate of $363 \mathrm{~m} \mathrm{Myr}^{-1 / 2}$ for the north flank, which is comparable to the average for midocean ridges (Parsons and Sclater, 1977). This information, along with an average ridge crest depth $(2750 \mathrm{~m})$, can be used as a starting point for Sites 213 and 215, such that

$z=\left(2750+363 t^{1 / 2}\right)-0.5 z(\mathrm{~s})$

If seafloor depths at Sites 213 and 215 adhered to Eq. (3), they should now lie at $5391 \mathrm{mb}$ b.s.l. (Site 213) and $5463 \mathrm{~m}$ b.s.l. (Site 215). The predicted depths are close but slightly off from actual depths $(-210 \mathrm{~m}$, Site $213 ;+154 \mathrm{~m}$, Site 215). Previous work regarding subsidence at Sites 213 and 215 (van Andel, 1975) has recognized this discrepancy, and thus different and deeper starting depths were given for Site 213 ( $3300 \mathrm{~m}$ b.s.l.) and Site $215(\sim 3100 \mathrm{~m}$ b.s.l.). These alternative "zero-age" depths imply slower subsidence rates, and ultimately deeper depth trajectories for both sites. There is no simple means to arrive at the correct depth trajectories over time, and different age or depth points along plausible curves should be taken as a reflection of uncertainty. For Sites 213 and 215, absolute depths for the early Paleogene may be off by $300-600 \mathrm{~m}$, depending on time since basalt emplacement. We do note, though, that at Sites 213 and 215, inclusion of the thin sedimentary packages $(\sim 150 \mathrm{~m})$ has minimal impact on the subsidence curve.

Site 214 on the crest of Ninetyeast Ridge has a much different depth trajectory than that at Sites 213 and 215. Aseismic ridges subside following the underlying plate as cooling and contraction progress, and at rates proportional to the square root of age (Detrick et al., 1977). However, if crustal age is significantly older than the hotspot (arbitrarily set at $3 \mathrm{Myr}$ at Site 214), cooling and contraction already will have initiated, which should result in slower subsidence (Detrick et al., 1977). For Site 214, we set a starting "depth" at $50 \mathrm{~m}$ above sea level, a height broadly consistent with lignites and volcaniclastics in lowermost cores, and neritic carbonate in subsequent cores. Thus, portions of Ninetyeast Ridge were once emergent volcanic islands, as inferred by others (Saunders et al., 1991; Frey et al., 1991; Carpenter et al., 2010). Using this starting height, we forced the subsidence $\left(286 \mathrm{~m} \mathrm{Myr}^{-1 / 2}\right)$ so the location of Site 214 slowly sank to $600 \mathrm{~m}$ b.s.l. by $48 \mathrm{Ma}$, and to $1655 \mathrm{~m}$ b.s.l. at present day. 
The significant and unexpected hiatus we document at Site 214 might be explained in multiple ways. The location could have been in shallow water ( $<500 \mathrm{~m}$ b.s.1.) between 58.33 and $53.85 \mathrm{Ma}$, and continually swept clean of sediment. Alternatively, it could represent a time of temporary uplift of underlying oceanic crust through compression (McKenzie and Sclater, 1971).

\subsection{CCD reconstruction for the early Paleogene central Indian Ocean}

The above age constraints and subsidence models permit records of carbonate content to be placed over time and depth to reconstruct the CCD (Fig. 10). As noted previously, the carbonate records at Site 214 generally can be ignored for this exercise, because this site was always much shallower than the CCD. However, the carbonate records at Sites 213 and 215 provide important information.

High carbonate contents, typically exceeding $80 \%$, characterize sediment over most of the lower portion of studied intervals at Site 213 and 215. For much of the late Paleocene and early Eocene, more specifically from 59 through $51 \mathrm{Ma}$, the CCD was significantly deeper than these locations. However, at both locations, carbonate contents dropped precipitously (to $<5 \%$ ) within calcareous nannofossil zone NP12. We suggest this transition from carbonate ooze to clay corresponds to a rapid rise in the CCD, which occurred between 52 and $50 \mathrm{Ma}$.

Moderate preservation of nannofossils spans most of the interval of high carbonate content at Sites 213 and 215. This observation suggests dissolution of microfossil assemblages, albeit relatively minor, and a seafloor location at or just below the lysocline. Such a setting would be expected along flanks of mid-ocean ridges, even though carbonate saturation horizons were probably shallower in the earliest Eocene relative to present-day (van Andel, 1975; Leon-Rodriguez and Dickens, 2010). Prior to the major drop in carbonate content and near the NP10-NP11 zonal boundary (i.e., about $54 \mathrm{Ma}$ ), preservation of nannofossils becomes poor at both Site 213 and 215 (Tables 5 and 7). This suggests the sites were further below the lysocline, either through subsidence or the rising of carbonate saturation horizons.

The generally lower carbonate contents at Site 213 compared to those at Site 215 requires explanation. This is because, with a standard crustal subsidence model, Site 213 should have been shallower than Site 215, especially during the early Paleogene (Fig. 10), and consequently should have better carbonate preservation. An obvious possibility is that crustal depths at time zero $\left(z_{(\mathrm{o})}\right.$, Eq. 1) were significantly different, and Site 213 was deeper than Site 215 by several hundred meters (van Andel, 1975). An intriguing alternative is that a very shallow Ninetyeast Ridge, as exemplified by the sediment record at Site 214, impeded east-west flow of water at intermediate to deep ocean depths. More specifically, the
CCD may have been shallower east of Ninetyeast Ridge for much of the early Paleogene.

Five brief drops in carbonate content span the thick interval of high carbonate at Site 213 (Fig. 7). Based on nannofossil datums and $\delta^{13} \mathrm{C}$ measurements, these carbonate lows may correspond to known hyperthermal events. From bottom to top, the first carbonate low (to $3 \%$ ) occurs within NP9 and definitely marks the PETM (Tremolada and Bralower, 2004), although sometime after the initial onset. The next three lows (to 40, 26, and 38\%) follow near and above the NP11-12 zonal boundary. These likely represent some combination of the $\mathrm{H}$, I, and $\mathrm{J}$ events, as the stratigraphic placement is approximately correct. However, it is difficult to make clear assignment because of major core disturbance. The uppermost carbonate low (to $2 \%$ ) lies near the Bc of D. lodoensis, and may represent the $\mathrm{K} / \mathrm{X}$ event. The $\mathrm{K} / \mathrm{X}$ event occurs near the Bc of D. lodoensis at other locations (Agnini et al., 2007; Dickens and Backman, 2013). The potential problem here is that the interval lies at the top of a core, where sediment is often admixed with younger material.

The PETM and the K/X event (assuming correctly identified) at Site 213 warrant special attention, because carbonate contents drop close to zero. This suggests the CCD rose significantly during these hyperthermals, effectively passing above the depth of the location. High carbonate contents immediately after the PETM (i.e., the two samples at 149.55 and $149.98 \mathrm{mcd}$ ) further suggest a carbonate "overshoot", where the CCD dropped to below that before massive carbon injection (e.g., Dickens et al., 1997; Kelly et al., 2012). A possible overshoot for the supposed K/X event would lie in a core gap. Presumably similar signals exist at Site 215, but these were not recovered because of core gaps.

\subsection{Comparison to previous work}

The reconstructed late Paleocene-early Eocene CCD for the central Indian Ocean (Fig. 10) is broadly consistent with that determined at several sites in the eastern Indian Ocean (Hancock et al., 2007) and equatorial Pacific Ocean (LeonRodriguez and Dickens, 2010; Pälike et al., 2012) (Fig. 1). In these works, the CCD was relatively deep in the latest Paleocene and earliest Eocene $(\sim 58$ to $52 \mathrm{Ma})$ but shoaled considerably in the late early Eocene $(\sim 52$ to $50 \mathrm{Ma})$. The magnitude of this shoaling remains poorly constrained, but probably exceeded several hundreds of meters. Importantly, at Sites 213 and 215 and other locations, the time when the CCD was relatively deep coincided with the long-term early Paleogene drop in $\delta^{13} \mathrm{C}$ (Figs. 1 and 10).

Previous reconstructions of the CCD (Berger, 1972; von der Borch and Sclater, 1974; van Andel, 1975; Rea and Lyle, 2005) had this horizon relatively shallow and flat through the early Eocene. This may have resulted from poorly resolved stratigraphy at a few key sites, including Sites 213 and 215. Initial reports of Leg 22 sediment cores identified the early Eocene shift from calcareous ooze to clay, but suggested it 
happened at Site 215 about $3 \mathrm{Myr}$ after it occurred at Site 213 (MacDougall, 1977; Peirce, 1978). This is not the case because the transition occurred within calcareous biozone NP12 at both sites (Fig. 10). The error seems to have led Gartner (1974, p. 582) to suggest a significant difference in starting ridge depth $\left(_{(0)}\right)$ between the two sites and a stationary CCD across the early Eocene, an interpretation that subsequently became incorporated into early CCD curves (van Andel, 1975).

The reconstructed CCD records at Sites 213 and 215 are somewhat similar to that at Site 1215 in the equatorial Pacific, which drilled into tholeitiic basalt of $58 \mathrm{Ma}$ age. At this location, the PETM and K/X event also are marked by particularly strong carbonate dissolution (LeonRodriguez and Dickens, 2010). Interestingly, at Site 1215, a good argument can be made for a long-term deepening of the lysocline beginning around $57 \mathrm{Ma}$ : the site was subsiding rapidly but, excluding hyperthermal events, the preservation of foraminifera tests generally remains similar or improves for several million years upcore (Leon-Rodriguez and Dickens, 2010). The available carbonate content and preservation records at Sites 213 and 215 neither support nor refute this concept. Site 215 would be helpful in this regard, as the sedimentary record begins at $59 \mathrm{Ma}$. However, in this discontinuous record, it is not obvious that the CCD or lysocline was particularly shallow at $58 \mathrm{Ma}$, nor that either horizon generally deepened between 58 and $53 \mathrm{Ma}$. There is only a slight drop in carbonate content between 58 and $57 \mathrm{Ma}$ (section 132).

Amongst existing Indian Ocean drill sites, only eight appear to contain sediment sequences amenable to reconstructing the early Paleogene CCD (Fig. 10). None of these sequences were recovered with multiple drill holes, and therefore they are discontinuous. Moreover, most of these sequences lack updated and revised stratigraphy, as well as sufficiently resolved carbonate content and stable isotope records. With available data, other locations in the Indian Ocean generally support the CCD record presented here, but also highlight a lack of detail and poor depth constraints.

\subsection{Significance toward early Paleogene carbon cycling}

Although our latest CCD reconstruction for the Indian Ocean remains poorly constrained, the coupled carbonate content and bulk carbonate $\delta^{13} \mathrm{C}$ records at Sites 213 and 215 support basic ideas and modeling efforts regarding early Paleogene carbon cycling. In particular and over multiple timescales, the highs and lows in $\delta^{13} \mathrm{C}$ seemingly relate to changes in net fluxes of organic carbon to and from the exogenic carbon cycle (e.g., Shackleton, 1986; Dickens et al., 1997; Kurtz et al., 2003; Zeebe et al., 2009; Cui et al., 2011; Komar et al., 2013). Long-term intervals with higher $\delta^{13} \mathrm{C}$ should correspond to less carbon in the ocean and atmosphere, and a shallower CCD; the opposite is also true. The CCD defined from records at Sites 213 and 215 generally tracks the $\delta^{13} \mathrm{C}$ of bulk carbonate, especially the rise in both records at $\sim 52.5 \mathrm{Ma}$. The short-term CIEs are a different matter, as they represent massive injections of organic carbon, each of which should result in a rapid rise in the CCD and lysocline, followed by overcompensation of these horizons. At Site 213, intense dissolution of carbonate occurs across the CIEs, especially the PETM and K/X.

The following are perhaps the two biggest issues currently confronting the scientific community in regards to early $\mathrm{Pa}-$ leogene carbon cycling: (1) what is the source or sources of organic carbon behind the long-term and short-term carbon cycle perturbations, and (2) are the long-term and short-term perturbations somehow related? As emphasized by several authors, much can be explained if the shallow geosphere has a large and dynamic organic carbon capacitor (Dickens, 2003, 2011; Kurtz et al., 2003; Komar et al., 2013). Effectively, some reservoir connected to the combined oceanatmosphere-biosphere can store massive amounts of organic carbon over long time intervals, and can return this carbon over both long and short timescales. In theory, potential organic carbon sources can be distinguished with combined records of $\delta^{13} \mathrm{C}$ and carbonate saturation horizons (e.g., Dickens et al., 1997; Zeebe et al., 2009; Cui et al., 2011; Komar et al., 2013), because the magnitude of changes in both parameters should relate to variations in carbon mass fluxes.

Even with the additional records presented here, causes of early Paleogene carbon cycle perturbations remain open to interpretation. For example, our Indian Ocean CCD curve can be compared to simulated "long-term" early Paleogene CCD curves predicted for the Atlantic and Pacific oceans (Komar et al., 2013; Fig. 11), which presumably should straddle the response in the Indian Ocean. Whilst changes in the CCD curves have similar timing, they have different magnitudes, by several hundreds of meters. This suggests the overall carbon cycling framework is correct, but either that mass flux variations in the modeling are too small or that depth constraints on CCD remain poorly characterized. Additional sites drilled on oceanic crust with ages between 75 and $55 \mathrm{Ma}$ are needed to resolve the problem.

\subsection{Recommendations for future drilling in the Indian Ocean}

The Indian Ocean is particularly relevant to studies of early Paleogene carbon cycling. This is because portions of three mid-ocean ridge segments and several aseismic ridges (e.g., Kerguelen Plateau, Ninetyeast Ridge, Broken Ridge, Chagos-Laccadive Ridge, Mascarene Plateau) are underlain by basalt of Late Cretaceous or Paleocene age (i.e., 75 and $55 \mathrm{Ma})$. As such, there exist multiple locations where targeted drilling could recover depth or latitude transects of early Paleogene deep-sea sediment, and from which detailed carbonate accumulation records might be generated. 


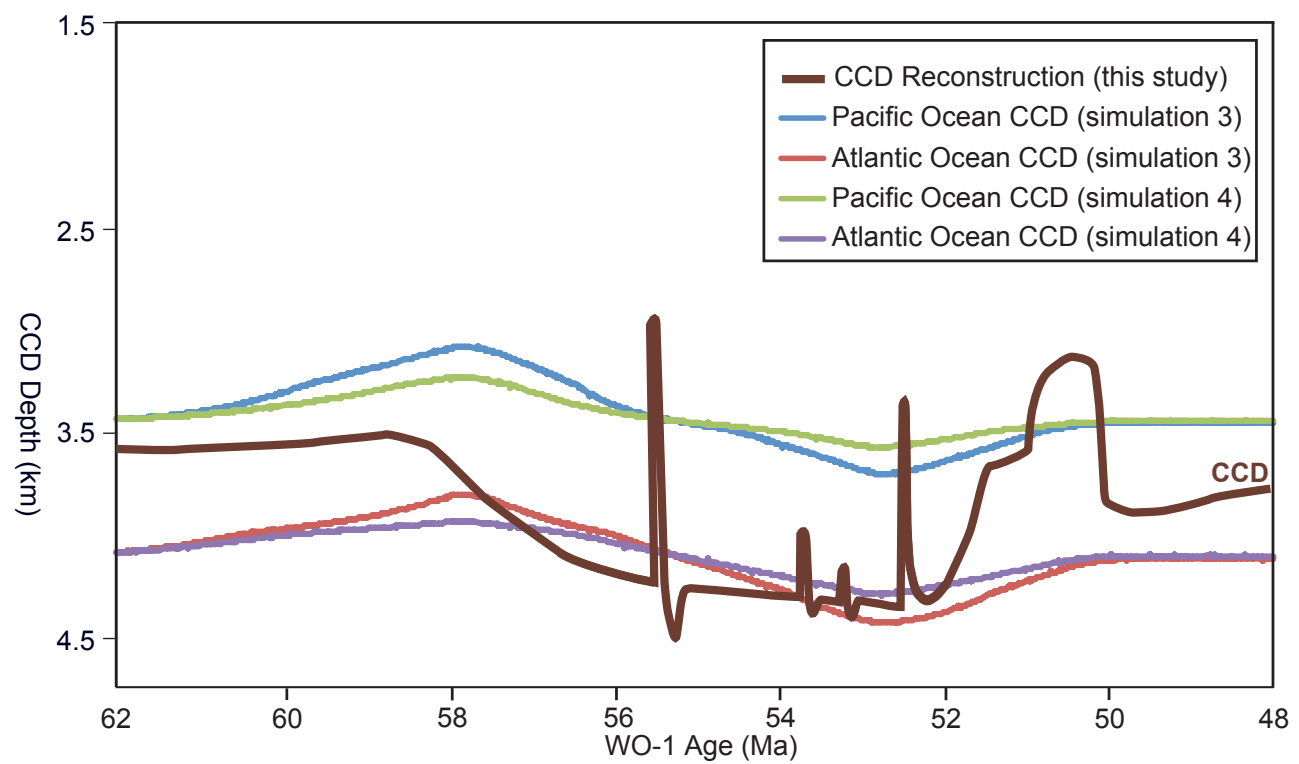

Figure 11. Comparison of data-derived CCD changes (brown, this study) to modeled CCD changes predicted for the Atlantic and Pacific oceans (green, purple, blue, and red) from 62-48 Ma (Komar et al., 2013). Records and models indicate a long-term ( $>1 \mathrm{Myr}$ ) CCD deepening from 58-52 Ma separated two intervals of CCD shoaling from 62 to $58 \mathrm{Ma}$ and 52 to $48 \mathrm{Ma}$. CCD curves have different magnitudes, by several hundreds of meters, suggesting the overall carbon cycling framework is correct but with a major caveat: either mass flux variations in the modeling are too small or CCD depth constraints require additional characterization.

Cores examined in this study suggest that high-quality early Paleogene CCD records might be generated in the central Indian Ocean. Certainly, relatively thick lower Paleogene sediment sections exist, and microfossil, carbonate content, and $\delta^{13} \mathrm{C}$ variations within these sequences can be correlated to other locations. Missing are sites with multiple drill holes where sediment recovery occurs through advanced piston coring (APC) techniques.

In the last 15 years or so, two drilling strategies have been employed in the Atlantic and Pacific oceans to reconstruct early Paleogene oceanographic conditions, including carbonate saturation horizons (Zachos et al., 2004; Pälike et al., 2010). The "Walvis Ridge strategy" involves drilling a series of sites down the flank of an aseismic ridge to obtain a depth transect (e.g., Zachos et al., 2004). This might be done on Ninetyeast Ridge, although ideally several hundred kilometers north of Site 214. The flanks of Ninetyeast Ridge in the vicinity of Site 214 have very little sediment (Veevers, 1974). By contrast, Site 216, also on the crest of Ninetyeast Ridge but $1550 \mathrm{~km}$ to the north, has a $457 \mathrm{~m}$ thick sediment section that terminates into Maastrichtian basalt (Shipboard Scientific Party, 1974); the flanks of the ridge in this location also have moderately thick sediment sections (Veevers, 1974). (We note that sediment recovery was particularly poor at Site 216, so we omitted this location from our study and from Fig. 10.)

The "Pacific Equatorial Age Transect" (PEAT) strategy involves drilling multiple locations at a nominally fixed position perpendicular to a ridge axis (Pälike et al., 2010). With this approach, specific short time slices can be recovered along ancient ridge flanks. Transects could be drilled parallel to Ninetyeast Ridge, which might include re-drilling of Sites 213 and 215, as well as targeting sediment sequences to the north, which should hold variably thick carbonate intervals above tholeiitic basalt emplaced during the Late Cretaceous and Paleocene.

\section{Summary and conclusions}

The early Paleogene was characterized by major changes in global carbon cycling as attested to by large amplitude variations in $\delta^{13} \mathrm{C}$ records of carbonate and organic carbon. A full understanding of these changes necessitates detailed records of contemporaneous carbonate accumulation on the seafloor. The early Paleogene CCD was poorly constrained prior to our work. Moreover, $\delta^{13} \mathrm{C}$ records and carbonate accumulation records rarely have been coupled together over millionyear time intervals. We have revised the stratigraphy and generated new carbonate content and $\delta^{13} \mathrm{C}$ records at three sites in the central Indian Ocean - Sites 213, 214, and 215 - in an effort to fill this knowledge gap.

A detailed early Paleogene CCD curve for the central Indian Ocean, while crucial to understanding carbon cycling during this time (Zeebe et al., 2009; Cui et al., 2011; Komar et al., 2013), cannot be generated with sedimentary records at available drill sites. This problem arises from several basic problems, as highlighted by the chosen sites. 
First, the tectonic history of the central Indian Ocean is complex and poorly constrained (Fisher and Sclater, 1983; Cande et al., 2010; Chatterjee et al., 2013). Reasonable estimates for initial depths and time trajectories can be derived for sites in the eastern equatorial Pacific (Leon-Rodriguez and Dickens, 2010), the region from which the most detailed early Paleogene CCD records have emerged (Pälike et al., 2012). Such estimates are not so clear for Sites 213, 214, and 215 in the central Indian Ocean.

Second, outdated drilling techniques have left us with tantalizing cores of poor quality. The sediment material from available central Indian Ocean sites is suitable for generating detailed carbonate accumulation and $\delta^{13} \mathrm{C}$ records. Although Site 214 is too shallow in the early Paleogene to provide constraints on carbonate saturation horizons, Sites 213 and 215 appear ideally located. However, only one hole was drilled at each site, and sediment coring occurred through rotary methods. Consequently, the recovered sections are incomplete and contain intervals with major sediment disturbance.

Third, new sites are needed to fully address the problem. Even if Sites 213 and 215 were re-drilled with modern techniques, including APC, companion sites would have to be drilled to the north, where crustal ages are older. This is because the CCD likely shoaled in the middle to late Paleocene, and deepened in the late Paleocene to early Eocene.

Despite the above problems, the new records of carbonate content and $\delta^{13} \mathrm{C}$ generated at Sites 213 and 215 add to our understanding of early Paleogene carbon cycling. The highs and lows in carbonate content and $\delta^{13} \mathrm{C}$ appear related, thus supporting ideas that major changes in net fluxes of organic carbon to and from the exogenic carbon cycle occurred during the early Paleogene.

\section{The Supplement related to this article is available online at doi:10.5194/cp-11-473-2015-supplement.}

Acknowledgements. This study used samples and data provided by the International Ocean Discovery Program. We thank workers from the Kochi Core Repository in Nankoku, Kochi, Japan, for all the time they put into sampling DSDP Leg 22 Sites on our behalf. We thank G. Snyder for overseeing and managing sample preparation in the geochemistry laboratory at Rice University, and A. van Dijk for helping with stable isotope analyses at Utrecht University. Andrea Dutton, and the two anonymous reviewers provided constructive comments that greatly improved the quality of the manuscript. Funding for this work principally came from NSF-FESD-OCE-1338842, awarded to C. T. Lee, G. R. Dickens, and colleagues, and a Vici grant of the Netherlands Organisation for Scientific Research (NWO) awarded to L. J. Lourens. A. Sluijs thanks the European Research Council for ERC starting grant \#259627 and the Royal Netherlands Academy of Arts and Sciences for a visiting professors grant for G. R. Dickens.

Edited by: T. Kiefer

\section{References}

Agnini, C., Muttoni, G., Kent, D.V., and Rio, D.: Eocene biostratigraphy and magnetic stratigraphy from Possagno, Italy: The calcareous nannofossil response to climate variability, Earth Planet. Sci. Lett., 241, 815-830, 2006.

Agnini, C., Fornaciari, E., Raffi, I., Rio, D., Rohl, U., and Westerhold, T.: High-resolution nannofossil biochronology of middle Paleocene to early Eocene at ODP Site 1262: Implications for Calcareous nannoplankton evolution, Mar. Micropaleontol., 64, 215-248, 2007.

Berger, W. H.: Deep sea carbonates: Dissolution facies and ageDepth constancy, Nature, 236, 392-395, 1972.

Berger, W. H.: Cenozoic sedimentation in the eastern tropical Pacific, Geol. Soc. Am. Bull., 84, 1941-1954, 1973.

Berggren, W. A. and Norris, R. D.: Biostratigraphy, Phylogeny, and Systematics of Paleocene Trochospiral Planktic Foraminifera, New York, NY (Micropaleontology Press, American Museum of Natural History), i-ii, 1-116, 1997.

Berggren, W. A. and Pearson, P. N.: A revised tropical Paleogene planktonic foraminiferal zonation, J. Foramin. Res., 35, 279298, 2005.

Boudreau, B. P., Middelburg, J. J., and Meysman, F. J. R.: Carbonate compensation dynamics, Geophys. Res. Lett., 37, L03603, doi:10.1029/2009GL041847, 2010.

Broecker, W. S.: A need to improve reconstructions of the fluctuations in the calcite compensation depth over the course of the Cenozoic, Paleoceanography, 23, PAI 204, doi:10.1029/2007PA001456, 2008.

Broecker, W. S. and Peng, T.-H.: Tracers in the Sea, Eldigio, edited by: Palisades, N. Y., 1-690, 1982.

Bukry, D.: Coccolith and silicoflagellate stratigraphy, Eastern Indian Ocean, Deep Sea Drilling Project, Leg 22, in: Initial Reports DSDP Leg 22, edited by: von der Borch, C. C. and Sclater, J. G., US Government Printing Office, Washington, 601-607, 1974.

Calcagno, P. and Cazenave, A.: Subsidence of the seafloor in the Atlantic and Pacific Oceans: Regional and large-scale variations, Earth Planet. Sci. Lett., 126, 473-492, 1994.

Cande, S. C., Patriat, P., and Dyment, J.: Motion between the Indian, Antarctic, and African plates in the early Cenozoic, Geophys. J. Internat., 183, 127-149, 2010.

Carpenter, R. J., Truswell, E. M., and Harris, W. K.: Lauraceae fossils from a volcanic Palaeocene oceanic island, Ninetyeast Ridge, Indian Ocean: ancient long-distance dispersal?, J. Biogeogr., 37, 1202-1213, 2010.

Charles, A .J., Condon, D. J., Harding, I. C., Pälike, H., Marshall, J. E. A., Cui, Y., Kump, L., and Croudace, I. W.: Constraints on the numerical age of the Paleocene-Eocene boundary, Geochem. Geophys. Geosys., 12, Q0AA17, doi:10.1029/2010GC003426, 2011.

Chatterjee, S., Goswami, A., and Scotese, C. R.: The longest voyage: Tectonic, magmatic, and paleoclimatic evolution of the Indian plate during its northward flight from Gondwana to Asia, Gondwana Res., 23, 238-267, 2013.

Cochran, J. R.: Variations in subsidence rates along intermediate and fast spreading mid-ocean ridges, Geophys. J. Roy. Astronom. Soc., 87, 421-454, 1986.

Coplen, T. B., Brand, W. A., Gehre, M., Gröning, M., Meijer, H. A. J., Toman, B., and Verkouteren, M.: New Guidelines for $\delta^{13} \mathrm{C}$ measurements, Anal. Chem., 78, 2439-2441, 2006. 
Cramer, B. S., Wright, J. D., Kent, D. V., and Aubry, M.-P.: Orbital climate forcing of $\mathrm{d} 13 \mathrm{C}$ excursion in the late Paleoceneearly Eocene (chrons C24n-C25n), Paleoceanography, 18, 1097, doi:10.1029/2003PA000909, 2003.

Cui, Y., Kump, L. R., Ridgwell, A. J., Charles, A. J., Junium, C. K., Diefendorf, A. F., Freeman, K. H., Urban, N. M., and Harding, I. C.: Slow Release of fossil carbon during the Palaeocene-Eocene Thermal Maximum, Nat. Geosci., 4, 481-485, 2011.

Detrick, R. S., Sclater, J. G., and Thiede, J.: The subsidence of aseismic ridges, Earth Planet. Sci. Lett., 34, 185-196, 1977.

Dickens, G. R.: Rethinking the global carbon cycle with a large, dynamic and microbially mediated gas hydrate capacitor, Earth Planet. Sci. Lett., 213, 169-183, 2003.

Dickens, G. R.: Down the Rabbit Hole: toward appropriate discussion of methane release from gas hydrate systems during the Paleocene-Eocene thermal maximum and other past hyperthermal events, Clim. Past, 7, 831-846, doi:10.5194/cp-7-831-2011, 2011.

Dickens, G. R. and Backman, J.: Core alignment and composite depth scale for the lower Paleogene through uppermost Cretaceous interval at Deep Sea Drilling Project Site 577, Newsletters on Stratigraphy, 46, 47-68, 2013.

Dickens, G. R., O’Neil, J. R., Rea, D. K., and Owen, R. M.: Dissociation of oceanica methane hydrate as a cause of the carbon isotope excursion at the end of the Paleocene, Paleoceanography, 10, 965-971, 1995.

Dickens, G. R., Castillo, M. M., and Walker, J. C. G.: A blast of gas in the latest Paleocene: Simulating first-order effects of massive dissociation of oceanic methane hydrate, Geology, 25, 259-262, 1997.

Expedition 329 Scientists: Site U1370, in: Proc. of the IODP, Volume 329, edited by: D'Hondt, S., Inagaki, F., Alvarez Zarikian, C.A., and the Expedition 329 Scientists, Tokyo, Integrated Ocean Drilling Program Management International, Inc., doi:10.2204/iodp.proc.329.108.2011, 2011.

Fisher, R. L. and Sclater, J. G.: Tectonic evolution of the Southwest Indian Ocean since the Mid-Cretaceous: plate motions and stability of the pole of Antarctica/Africa for at least $80 \mathrm{Myr}$, Geophys. J. Roy. Astrol. Soc., 73, 553-576, 1983.

Frey, F. A., Dickey Jr., J. S., Thompson, G., and Bryan, W. B.: Eastern Indian Ocean DSDP sites: Correlations between petrography, geochemistry and tectonic setting, in: A synthesis of deep sea drilling in the Indian Ocean, edited by: Heirtzler, J. R., and Sclater, J. G., Washington, DC, US Government Printing Office, 189-257, 1977.

Frey, F. A., Jones, W. B., Davies, H., and Weis, D.: Geochemical and petrologic data for basalts from Site 756, 757, and 758: implications for the origin and evolution of Ninetyeast Ridge, in: Proc. ODP Sci. Results, volume 121, edited by: Weissel, J., Peirce, J., Taylor, E., Alt, J., et al., College Station, TX Ocean Drilling Program, 611-659, 1991.

Frey, F. A., Pringle, M., Meleney, P., Huang, S., and Piotrowski, A.: Diverse mantle sources for Ninetyeast Ridge magmatism: Geochemical constraints from basaltic glasses, Earth Planet. Sci. Lett., 303, 215-224, 2011.

Galeotti, S., Krishnan, S., Pagani, M., Lanci, L., Gaudio, A., Zachos, J. C., Monechi, S., Morelli, G., and Lourens, L.: Orbital chronology of Early Eocene Hyperthermals form the Contessa
Road Section, central Italy, Earth Planet. Sci. Lett., 290, 192200, 2010.

Gartner, S.: Nannofossil biostratigraphy, Leg 22. Deep Sea Drilling Project, in: Initial Reports, DSDP Leg 22, edited by: von der Borch, C. C. and Sclater, J. G., US Government Printing Office, Washington, 577-599, doi:10.2973/dsdp.proc.22.126.1974, 1974.

Hagelberg, T., Shackleton, N., Pisias, N., and Shipboard Scientific Party: Development of Composite Depth Sections for Sites 844 through 854, in: Proceedings of the Ocean Drilling Program, Initial Reports, V. 138, edited by: Mayer, L., Pisias, N., Janecek, T., et al., College Station, TX Ocean Drilling Program, 79-85, 1992.

Hancock, H. J. L., Dickens, G. R., Thomas, E., and Blake, K. L.: Reappraisal of early Paleogene CCD curves: foraminiferal assemblages and stable carbon isotopes across the carbonate facies of Perth Abyssal Plain, Int. J. Earth Sci., 96, 925-946, 2007.

Hilgen, F. J., Kuiper, K. F., and Lourens, L. J.: Evaluation of the astronomical time scale for the Paleocene and earliest Eocene, Earth Planet. Sci. Lett., 300, 139-151, 2010.

Hovan, S. A. and Rea, D. K.: Paleocene/Eocene boundary changes in atmospheric and oceanic circulation: A Southern Hemisphere record, Geology, 20, 15-18, 1992.

Kelly, D. C., Nielsen, T. M. J., McCarren, H. K., Zachos, J. C., and Röhl, U.: Spatiotemporal patterns of carbonate sedimentation in the South Atlantic: Implications for carbon cycling during the Paleocene-Eocene thermal maximum, Palaeogeography, Palaeoclimatology, Palaeoecology, 293, 30-40, 2010.

Kelly, D. C., Nielsen, T. M. J., and Schellenberg, S. A.: Carbonate saturation dynamics during the Paleocene-Eocene thermal maximum: Bathyal constraints from ODP sites 689 and 690 in the Weddell Sea (South Atlantic), Mar. Geol., 303-306, 75-86, 2012.

Kennett, J. P.: Marine Geology, Englewood Cliffs, NJ (PrenticeHall, Inc.), 1-813, 1982.

Kennett, J. P. and Stott, L. D.: Abrupt deep-sea warming, palaeoceanographic changes and benthic extinctions at the end of the Palaeocene, Nature, 353, 225-229, 1991.

Klein, E. M., Langmuir, C. H., and Staudigel, H.: Geochemistry of Basalts from the Southeast Indian Ridge, $115-138^{\circ}$ E, J. Geophys. Res., 96, 2089-2107, 1991.

Komar, N., Zeebe, R. E., and Dickens, G. R.: Understanding longterm carbon cycle trends: The late Paleocene through the early Eocene, Paleoceanography, 28, 650-662, 2013.

Kump, L. R., Bralower, T. J., and Ridgwell, A.: Ocean acidification in deep time, Oceanography, 22, 94-107, 2009.

Kurtz, A. C., Kump, L. R., Arthur, M. A., Zachos, J. C., and Paytan, A.: Early Cenozoic decoupling of the global carbon and sulfur cycles, Paleoceanography, 18, 1090, doi:10.1029/2003PA000908, 2003.

Leon-Rodriguez, L. and Dickens, G. R.: Constraints on ocean acidification associated with rapid and massive carbon injections: The early Paleogene record at ocean drilling program site 1215, equatorial Pacific Ocean, Palaeogeography, Palaeoclimatology, Palaeoecology, 298, 409-420, 2010.

Lisiecki, L. E. and Herbert, T. D.: Automated composite depth scale construction and estimates of sediment core extension, Paleoceanography, 22, PA4213, doi:10.1029/2006PA001401, 2007. 
MacDougall, J. D.: Uranium in Marine Basalts: Concentration, Distribution and Implications, Earth Planet. Sci. Lett., 35, 65-70, 1977.

Mahoney, J. J., Graham, D. W., Christie, D. M., Johnson, K. T .M., Hall, L. S., and Vonderhaar, D. L.: Between a Hotspot and a Cold Spot: Isotopic Variation in the Southeast Indian Ridge Asthenosphere, 86-118 E, J. Petrol., 43, 1155-1176, 2002.

Martini, E.: Standard Tertiary and Quaternary calcareous nannoplankton zonation, in: Proceedings of the 2 nd International Conference of Planktonic Microfossils Roma, edited by: Farinacci, A., Rome (Ed. Tecnosci.), 2, 739-785, 1971.

McGowran, B.: Foraminifera, Leg 22. Deep Sea Drilling Project, in: Initial Reports, DSDP Leg 22, edited by: von der Borch, C. C. and Sclater, J. G., US Government Printing Office, Washington, 577-599, 1974.

McKenzie, D. and Sclater, J. G.: The Evolution of the Indian Ocean since the Late Cretaceous, Geophys. J. Roy. Astronom. Soc., 25, 437-528, 1971.

Nicolo, M. J., Dickens, G. R., Hollis, C. J., and Zachos, J. C.: Multiple early Eocene Hyperthermals: Their sedimentary expression on the New Zealand continental margin and in the deep sea, Geology, 35, 699-702, 2007.

Ocean Drilling Stratigraphic Network, available at: http://www. odsn.de, 2011.

Pälike, H., Nishi, H., Lyle, M., and Shipboard Scientific Party: Expedition 320/321 summary, in: Proceedings of the Integrated Ocean Drilling Program, 320/321, edited by: Pälike, H., Lyle, M., Nishi, H., Raffi, I., Gamage, K., Klaus, A., and the Expedition 320/321 Scientists, Integrated Ocean Drilling Program Management International, Inc., Tokyo, doi:10.2204/iodp.proc.320321.101.2010, 2010.

Pälike, H., Lyle, M. W., Nishi, H., et al.: A Cenozoic record of the equatorial Pacific carbonate compensation depth, Nature, 488, 609-615, 2012.

Parsons, B. and Sclater, J. G.: An Analysis of the Variation of Ocean Floor Bathymetry and Heat Flow with Age, J. Geophys. Res., 82, 803-827, 1977.

Patriat, P. and Achache, J.: India-Eurasia collision chronology has implications for crustal shortening and driving mechanisms of plates, Nature 311, 615-621, 1984.

Patterson, W. P. and Walter, L. M.: Syndepositional diagenesis of modern platform carbonates: Evidence from isotopic and minor element data, Geology, 22, 127-130, 1994a.

Patterson, W. P. and Walter, L. M.: Depletion of ${ }^{13} \mathrm{C}$ in seawater $\Sigma \mathrm{CO}_{2}$ on modern carbonate platforms: Significance for the carbon isotopic record of carbonates, Geology, 22, 885-888, 1994 b.

Peirce, J. W.: The northward motion of India since the Late Cretaceous, Geophys, J. R. Astr. Soc., 52, 277-311, 1978.

Pimm, A. C.: Sedimentology and History of the Northeastern Indian Ocean from Late Cretaceous to Recent, in: Initial Reports of the Deep Sea Drilling Project, Volume 22, edited by: von der Borch, C. C., Sclater, J. G., et al., US Government Printing Office, Washington, 119-191, 1974.

Ravizza, G., Norris, R. N., Blusztajn, J., and Aubry, M-P.: An osmium isotope excursion associated with the late Paleocene thermal maximum: Evidence of intensified chemical weathering, Paleoceanography, 16, 155-163, 2001.
Rea, D. K. and Lyle, M. W.: Paleogene calcite compensation depth in the eastern subtropical Pacific: Answers and questions, Paleoceanography, 20, PA1012, doi:10.1029/2004PA001064, 2005.

Ruddiman, W. F., Cameron, D., and Clement, B. M.: Sediment Disturbance and Correlation of Offset Holds Drilled with the Hydraulic Piston Corer, Leg 94, in: Initial Reports of the Deep Sea Drilling Project Leg 94, edited by: Ruddiman, W. F., Kidd, R. B., Thomas, E., et al., Washington, US Government Printing Office, 1987.

Sanders, D.: Syndepositional dissolution of calcium carbonate in neritic carbonate environments: geological recognition, processes, potential significance, J. Afr. Earth Sci., 36, 99-134, 2003.

Saunders, A. D., Storey, M., Gibson, I. L., Leat, P., Hergt, J., and Thompson, R. N.: Chemical and Isotopic Constraints on the origin of basalts from Ninetyeast Ridge, Indian Ocean: Results from DSDP Legs 22 and 26 and ODP Leg 121, in: Proceedings of the Ocean Drilling Program, Scientific Results, Volume 121, edited by: Weissel, J., Peirce, J., Taylor, E., Alt, J., et al., College Station, TX Ocean Drilling Program, 559-590, 1991.

Sclater, J. G., Anderson, R. N., and Lee Bell, M.: Elevation of Ridges and Evolution of the Central Eastern Pacific, J. Geophys. Res., 76, 7888-7915, 1971.

Shackleton, N. J.: Paleogene Stable Isotope Events, Palaeogeography, Palaeoclimatology, Palaeoecology, 57, 91-102, 1986.

Shackleton, N. J., Hall, M. A., and Bleil, U.: Carbon-isotope stratigraphy, site 577, in: Initial Reports of the Deep Sea Drilling Project, Volume 86, edited by: Turner, K. L., US Government Printing Office, Washington, 503-511, 1985.

Shipboard Scientific Party: Site 216, in: Initial Reports of the Deep Sea Drilling Project, Volume 22, edited by: von der Borch, C. C., Sclater, J. G., et al., US Government Printing Office, Washington, 213-265, 1974a.

Shipboard Scientific Party: Site 236, in: Initial Reports of the Deep Sea Drilling Project, Volume 24, edited by: Fisher, R. L, Bunce, E. T., et al., US Government Printing Office, Washington, 327389, 1974b.

Shipboard Scientific Party: Site 245, in: Initial Reports of the Deep Sea Drilling Project, Volume 25, edited by: Simpson, E. S. W., Schlich, R., et al., US Government Printing Office, Washington, 187-236, 1974c.

Shipboard Scientific Party: Site 756, in: ODP Init. Reps, 121, edited by: Peirce, J., Weissel, J., et al., College Station, TX, Ocean Drilling Program, 259-303, 1989a.

Shipboard Scientific Party: Site 757, in: Proc. ODP Init. Reps, 121, edited by: Peirce, J., Weissel, J., et al., College Station, TX, Ocean Drilling Program, 305-358, 1989b.

Shipboard Scientific Party: Site 758, in: Proc. ODP Init. Reps, 121, edited by: Peirce, J., Weissel, J., et al., College Station, TX, Ocean Drilling Program, 359-453, 1989c.

Shipboard Scientific Party: Site 766, in: Proc. ODP Init. Reps, 123, edited by: Gradstein, F. M., Ludden, J. N., Adamson A. C., et al., College Station, TX, Ocean Drilling Program, 269-352, 1990.

Shipboard Scientific Party: Leg 179 summary, in: Proc. ODP, Init. Reps., 179, edited by: Pettigrew, T. L., Casey, J. F., Miller, D. J., et al., College Station, TX, Ocean Drilling Program, 1-26, 1999.

Shipboard Scientific Party: Site 1219, in: Proc. ODP Init. Reps, 199, edited by: Lyle, M., Wilson, P. A., Janecek T. R., et al., College Station, TX, Ocean Drilling Program, 1-129, 2002a. 
Shipboard Scientific Party: Site 1220, in: Proc. ODP Init. Reps, 199, edited by: Lyle, M., Wilson, P.A., Janecek T.R., et al., College Station, TX, Ocean Drilling Program, 1-93, 2002b.

Slotnick, B.S., Dickens, G.R., Nicolo, M.J., Hollis, C.J., Crampton, J.S., and Zachos, J.C., Sluijs, A.: Numerous large amplitude variations in carbon cycling and terrestrial weathering throughout the latest Paleocene and earliest Eocene, The J. Geol., 120, 487-505, 2012.

Sluijs, A., Bowen, G., Brinkhuis, H., Lourens, L. J., and Thomas, E.: The Palaeocene-Eocene Thermal Maximum super greenhouse: biotic and geochemical signatures, age models and mechanisms of global change, in: Deep-Time Perspectives on Climate Change: Marrying the Signal from Computer Models and Biological Proxies, edited by: Williams, M., Haywood, A. M., Gregory, J., and Schmidt, D. N., The Micropaleontological Society, Special Publications, London, 323-349, 2007.

Stap, L., Sluijs, A., Thomas, E., and Lourens, L.: Patterns and magnitude of deep sea carbonate dissolution during Eocene Thermal Maximum 2 and H2, Walvis Ridge, southeastern Atlantic Ocean, Paleoceanography, 24, PA1211, doi:10.1029/2008PA001655, 2009.

Stap, L., Lourens, L. J., Thomas, E., Sluijs, A., Bohaty, S., and Zachos, J.C.: High resolution deep-sea carbon and oxygen isotope records of Eocene Thermal Maximum 2 and H2, Geology, 38, 607-610, 2010 .

Storms, M. A.: Ocean Drilling Program (ODP) Deep Sea Coring Techniques, Mar. Geophys. Res., 12, 109-130, 1990.

Swart, P. K. and Eberli, G.: The nature of the $\delta^{13} \mathrm{C}$ of periplatform sediments: Implications for stratigraphy and the global carbon cycle, Sediment. Geol., 175, 115-129, 2005.

Tremolada, R. and Bralower, T. J.: Nannofossil assemblage fluctuations during the Paleocene-Eocene Thermal Maximum at Sites 213 (Indian Ocean) and 401 (North Atlantic Ocean): palaeoceanographic implications, Mar. Micropaleontol., 52, 107-116, 2004.

van Andel, T. H.: Mesozoic/Cenozoic Calcite Compensation Depth and the global distribution of calcareous sediments, Earth Planet. Sci. Lett., 26, 187-194, 1975.

Vandenberghe, N., Hilgen, F. J., and Speijer, R. P.: The Paleogene Period, in: The Geologic Time Scale 2012, edited by: Gradstein, F., Ogg, J., Schmitz, M., Ogg, G., Amsterdam, the Netherlands (Elsevier BV), 855-922, 2012.
Veevers, J. J.: 10. Seismic profiles made underway on Leg 22, in: Initial Reports, DSDP Leg 22, edited by: von der Borch, C. C. and Sclater, J. G., Washington, US Government Printing Office, 351-367, 1974.

von der Borch, C. C. and Sclater, J. G.: Initial Reports, DSDP Leg 22, Washington, US Government Printing Office, 1-599, doi:10.2973/dsdp.proc.22.126.1974, 1974.

Westerhold, T. and Röhl, U.: High resolution cyclostratigraphy of the early Eocene - new insights into the origin of the Cenozoic cooling trend, Clim. Past, 5, 309-327, doi:10.5194/cp-5309-2009, 2009.

Westerhold, T., Röhl, U., Raffi, I., Fornaciari, E., Monechi, S., Reale, V., Bowles, J., and Evans, H. F.: Astronomical calibration of the Paleocene time, Palaeogeogr., Palaeoclimatol., Palaeoecol., 257, 377-403, 2008.

Zachos, J. C., Rea, D.K., Seto, K., Nomura, R., and Niitsuma, N.: Paleogene and Early Neogene Deep Water Paleoceanography of the Indian Ocean as Determined from Benthic Foraminifer Stable Carbon and Oxygen Isotope Records, Geophys. Monogr. Ser., 70, 351-385, 1992.

Zachos, J. C., Pagani, M., Sloan, L., Thomas, E., and Billups, K.: Trends, rhythms, and aberrations in global climate $65 \mathrm{Ma}$ to present, Science, 292, 686-693, 2001.

Zachos, J. C., Kroon, D., Blum, P., Bowles, J., Gaillot, P., Hasegawa, T., Hathorne, E. C., and Shipboard Scientific Party: Proceedings of the Ocean Drilling Program, Initial Reports, 208, doi:10.2973/opd.proc.ir.208.2004, 2004.

Zachos, J. C., Röhl, U., Schellenberg, S. A., Sluijs, A., Hodell, D. A., Kelly, D. C., Thomas, E., Nicolo, M., Raffi, I., Lourens, L. J., McCarren, H., and Kroon, D.: Rapid Acidification of the Ocean During the Paleocene-Eocene Thermal Maximum, Science, 208, 1611-1615, 2005.

Zachos, J. C., McCarren, H., Murphy, B., Rohl, U., and Westerhold, T.: Tempo and scale of late Paleocene and early Eocene carbon isotope cycles: Implications for the origin of hyperthermals, Earth Planet. Sci. Lett., 299, 242-249, 2010.

Zeebe, R. E. and Westbroek, P.: A simple model for the $\mathrm{CaCO}_{3}$ saturation state of the ocean: The "Strangelove," the "Neritan," and the "Cretan" Ocean, Geochem. Geophys. Geosyst., 4, 1104, doi:10.1029/2003GC000538, 2003.

Zeebe, R. E., Zachos, J. C., and Dickens, G. R.: Carbon dioxide forcing along insufficient to explain PalaeoceneEocene Thermal Maximum warming, Nat. Geosci., 2, 576-580, doi:10.1038/NGEO578, 2009. 